\title{
A Closer Look: A Symposium Among Legal Historians and Law Librarians to Uncover the Spanish Roots of Louisiana Civil Law ${ }^{\dagger}$
}

\author{
VINCENÇ FILIU*, DENNIS KIM-PRIETO**, AND TERESA MIGUEL ${ }^{* *}$
}

\begin{abstract}
The debate regarding whether the origin of Louisiana civil law is based in the Spanish or in the French legal tradition has been ongoing since that state's incorporation into the United States as a result of the Louisiana Purchase. Distinguished legal scholars have argued in favor of one tradition being dominant over the other, and each has been staunch in support of that view. This article proposes and demonstrates that the Spanish, not French, civil law had an enormous influence on the creation and evolution of Louisiana civil law, and that this legacy resonates today.
\end{abstract}

The article begins with a brief historical account of the formation of Louisiana from territory to statehood. It then closely examines the

\footnotetext{
${ }^{\dagger}$ This article is derived from a symposium of experts in legal history and legal bibliography particular to the state of Louisiana. They are: ProfessorAlain Levasseur, Moyse Professor of Law, and Professor Vicenç Feliú, former Assistant Director for Public Services and Associate Librarian for Foreign, Comparative, and International Law at the Louisiana State University Paul M. Hebert Law Center; Professor Raphael J. Rabalais, Sarpy Distinguished Professor at the Loyola University New Orleans College of Law; and Mr. William T. Tête, Of Counsel for Medo \& Tête and Adjunct Professor of Law at Loyola University New Orleans College of Law. The panelists presented key documents that contributed to the development of Louisiana civil law, placed these documents into their proper historical context, and explained how each was influential as the civil law of Louisiana evolved over the course of the last 200 years. This symposium, entitled "A Closer Look: Uncovering the Spanish Roots of Louisiana Civil Law," was held on 17 July 2007 in New Orleans as a featured program of the $100^{\text {th }}$ Annual Meeting of the American Association of Law Libraries.

* Director of the Law Library and Assistant Professor of Law, University of the

District of Columbia, David A. Clarke School of Law, Mason Law Library.

** Reference Librarian at Rutgers University-Newark Law Library.

*** Associate Librarian for Foreign and International Law at the Lillian Goldman Law Library, Yale Law School.
} 
contributions of Louis Casimir Elisabeth Moreau Lislet, the architect of the Digest of 1808 and the Code of 1825 . Original Spanish documents and resources that were the foundation of the Digest of 1808 are analyzed and used to demonstrate how these Spanish civil law sources had a profound impact on Moreau Lislet and on the creation of Louisiana civil law. Finally, we carefully examine the continuing evolution of Louisiana civil law and the now-famous Batiza-Pascal debate on the origins of the Louisiana civil law. ${ }^{\prime}$

\section{Introduction}

The debate regarding whether the origin of Louisiana civil law is based on the Spanish or the French legal tradition has been ongoing since the state's incorporation into the United States as a result of the Louisiana Purchase. $^{2}$ Distinguished legal scholars have argued in favor of one tradition being dominant over the other, and each has been staunch in support of that view. ${ }^{3}$ In this article we propose and demonstrate that the Spanish, not French, civil law had an enormous influence on the creation and evolution of Louisiana civil law, and that this legacy resonates today.

This article begins with a brief historical account of the formation of Louisiana from territory to statehood. We then closely examine the contributions of Louis Casimir Elisabeth Moreau Lislet, the architect of the Digest of $1808^{4}$ and the Code of $1825^{5}$ In doing so, we analyze original

${ }^{1}$ This paper is a combined effort of all three writers reflecting the ideas presented by our four speakers. We are particularly grateful to Profs. Levasseur, Rabalais, and Tête for the enthusiasm and authority their participation brought to this symposium. The symposium was conceived and moderated by Teresa M. Miguel. Both Dennis Kim-Prieto, co-moderator, and Vicenç Feliu, speaker, assisted additionally in the symposium's organization and with the coordination of the panelists. Audio of the panel presentation can be purchased from Mobiltape:

http://www.mobiltape.com/conference/AALL-100th-Annual-Meeting (last visited February 8, 2011).

${ }^{2}$ Editorial, The Louisiana GazeTte, Friday, November 9, 1804.

${ }^{3}$ See, e.g., Rodolfo Batiza, The Louisiana Civil Code of 1808: Its Actual Sources and Present Relevance, 46 TUL. L. REV. 4 (1972); Robert A. Pascal, Sources of the Digest of 1808: A Reply to Professor Batiza, 46 TUL. L. REV. 603 (1972); Rodolfo Batiza, Sources of the Civil Code of 1808, Facts and Speculation: A Rejoinder, 46 TUL. L. REV. 628 (1972); A.N. Yiannopoulos, The Early Sources of Louisiana Law: Critical Appraisal of a Controversy, in LouISIANA's LEGAL HERITAGE 87 (Edward F. Haas, ed., 1983).

${ }^{4}$ LOUIS MOREAU LISLET \& JAMES BROWN, A Digest OF THE CIVIL LAWS NOW IN FORCE IN THE TERRITORY OF ORLEANS, WITH ALTERATIONS AND AMENDMENTS 
Spanish documents and resources that were the foundation of the Digest of 1808. We demonstrate that these Spanish civil law sources had a profound impact on Moreau Lislet and on the creation of Louisiana civil law. This leads us into the continuing evolution of Louisiana civil law and the nowfamous Batiza-Pascal debate on the origins of the Louisiana civil law. ${ }^{6}$

\section{Colonial Luisiana and the Context of Spanish Law}

The Spanish heritage in Louisiana is apparent throughout the state and its people. It can be seen, for example, in the Spanish architecture dominating the French Quarter of New Orleans ${ }^{7}$ as well as in the legal traditions that flow from Spain to Louisiana. ${ }^{8}$ The Spanish Colonial period in Luisiana began dramatically. The residents of Louisiana were overwhelmingly French when the Spanish gained possession of Louisiana, and they were not aware that the Louisiana territory had been transferred to Spain. Therefore, when the Spanish colonial governors arrived in New Orleans, the capital of the Spanish province of Luisiana, the French colonists were very suspicious and reluctant to give up allegiance to France. In 1768, the residents of New Orleans, after a period of some tension and as a show of

ADAPTED to ITS PRESENT SySTEM OF GoVERNMENT (New Orleans, Bradford \& Anderson 1808) (herinafter, Digest of 1808).

${ }^{5}$ Louisiana CIVIL CODE OF 1825.

${ }^{6}$ Batiza and Pascal supra note 3.

${ }^{7}$ The influence of Spanish architecture emerged in the rebuilding of New Orleans after two fires (1788 and 1794) that destroyed many buildings that had been erected during the previous French period. Observation of Professor Raphael Rabalais, delivered in "A Closer Look: Uncovering the Spanish Roots of the Louisiana Civil Law," Annual Meeting of Annual Association of Law Libraries (17 July 2007).

${ }^{8}$ Many primary documents available for research pertaining to the Spanish Colonial period are housed in New Orleans. Loyola University New Orleans played a major role in microfilming the largest collection of Spanish Colonial documents housed in the General Archives of the Indies in Seville. Thus, it is possible to use 140,000 pages of archived material without traveling to Seville. See Raphael J. Rabalais, The Influence of Spanish Laws and Treatises on the Jurisprudence of Louisiana: 1762-1828, 42 LA. L. REV. 1494-1508 (1982) for a detailed treatment of this preservation as well as an analysis of the contents of these documents. Additionally, the Notarial Archives in New Orleans consists of about 220,000 manuscript pages from the Spanish colonial period. Though some of them were damaged in Hurricane Katrina, they were very quickly preserved, and the majority of these documents are still usable. For an overview of the colonial judicial materials collected therein, see New Orleans Notarial Archives, Research Center and Historical Documents, http://www.notarialarchives.org/research.htm (last visited Dec. 11, 2008). 
their loyalty to France, escorted Spanish Governor Ulloa to a ship in the Mississippi River and cut the anchor so his ship would float off into the Gulf of Mexico. ${ }^{9}$

Shortly thereafter, on August 18, 1769, Alexander O'Reilly landed in Louisiana with more than 2000 trained Spanish troops and took possession of New Orleans, a city of no more than 10,000 people at the time. He invited leaders of the resistance to his headquarters where he promptly arrested them. ${ }^{10}$ O'Reilly restored order quickly, and almost immediately began to implement laws as set out in the Recopilación de Leyes de los Reynos de las Indias (1680), a compilation of laws written for the Spanish colonies in the Americas. ${ }^{11}$

The new laws provided for a local cabildo, or governing council, which was composed of members with some legal responsibilities, and an alcalde, or provincial mayor, whose office was purchased, as was common practice in the French parliament. ${ }^{12}$ There were also judges who were elected and who were not subject to the requirements of being legal professionals. Local university-trained officials, the auditor de guerra and the asesor, provided these elected judges with guidance as the judges presided over judicial proceedings in line with international norms for justice at the time. ${ }^{13}$

The Spanish colony of Louisiana became more and more prosperous as settlers crossed over the Appalachian and Allegheny Mountains. As a matter of geography and transportation, the natural marketplace for the sale of goods farmed from this land was at the mouth of the Mississippi River. Farmers who grew grain would often distill it into whisky to glean some value instead of allowing their crop to rot. As a result, enormous quantities of

${ }^{9}$ Rabalais, supra note 8 , at 1487 .

${ }^{10}$ Id. at 1487.

${ }^{11}$ Id. See infra Section IV.C.

12 The Louisiana State Museum holds many Spanish judicial records from the alcaldes. This collection is approximately 200-300 linear feet of Spanish judicial documents. A researcher translated a précis of these documents from 1923-1948, but only completed translating documents up to the year 1785 . For a complete description of the colonial judicial materials collected therein, see Louisiana State Museum Historical Center, Summary of Collections (excluding books) (http://lsm.crt.state.la.us/collections/hcenter.htm, last visited March 17, 2009).

${ }^{13}$ For a concise discussion of O'Reilly's ordinances and instructions, See Shael Herman, Under My Wings Every Thing Prospers: Reflections Upon Vernon Palmer's "The Louisiana Civilian Experience--Critiques of Codification in a Mixed Jurisdiction," 80 TUL. L.REV. 1491 (2006) (book review). 
whisky ended up for sale at the marketplace at the mouth of the Mississippi River. At that time, alcohol was not simply used for social purposes, but was also a significant caloric supplement and a source of potable water for people engaged in lives of hard manual labor, burning thousands of calories per day towards their subsistence. ${ }^{14}$

Towards the end of the Spanish colonial period, the city of New Orleans became immensely wealthy and valuable, much like an American version of Venice. New Orleans, being below sea level, was a major source for the transfer of goods and overseas trade. ${ }^{15}$ Compared to other Spanish colonies in the Americas, New Orleans had an extremely high per capita income. ${ }^{16}$

The institution of slavery was practiced under French and Spanish colonial rule, but in 1792, the local cabildo adopted a resolution to stop the entry of slaves. ${ }^{17}$ The justification for this effort may have foreshadowed the slave rebellion just three years later in Point Coupée parish, slightly north of Baton Rouge today. ${ }^{18}$ Thus, during the waning years of Spanish rule, the importation of slaves stopped and did not resume until after the Louisiana Purchase.

At the very end of Spanish colonial rule, political and governmental conditions had deteriorated. Spain was under increasing pressure from France, and was making concessions to Napoleon. ${ }^{19}$ In October 1800 , Spain

${ }^{14}$ Rabalais, supra note 7.

${ }^{15}$ See James T. McHugh, On the Dominant Ideology of the Louisiana Constitution, 59 ALB. L. REV. 1583 (1996)(citing ALCEE FORTIER, A HISTORY OF LOUISIANA 30-49 [1904] for the text of a letter dated Aug. 10, 1776, from Don Francisco Bouligny, Captain of the Battalion of Infantry of Spanish Louisiana, to Don Josef de Galvez, Minister of the Indies, on behalf of Charles III, King of Spain, detailing the myriad development opportunities then available in Spanish Colonial Louisiana.)

${ }^{16}$ See Shael Herman, The Contribution of Roman Law to the Jurisprudence of Antebellum Louisiana, 56 LA. L. REV. at 262 (citing GEORGE DARGO, JEFFERSON'S LOUISIANA: POLITICS AND THE CLASH OF LEGAL TRADITIONS [1975]) for a concise summary of the economic conditions in Louisiana near the end of the Spanish colonial period.

${ }^{17}$ See Rabalais, supra note 8, citing Batiza, The Louisiana Civil Code of 1808: Its Actual Sources and Present Relevance, 46 TUL. L. REV. 11-12 (1971).

${ }^{18}$ For a discussion of the events leading up to the rebellion in Pointe Coupeé, see Vernon V. Palmer, The Customs of Slavery: the War without Arms, 48 AM. J. LEGAL HisT. 177 (2006).

${ }^{19}$ See James T. McHugh, On the Dominant Ideology of the Louisiana Constitution, 59 ALB. L. REV. 1583-1585 (1996) for a brief description of the political 
secretly agreed to retrocede Louisiana to France. Napoleon planned to send a large army of 30,000 troops, first to eradicate a slave rebellion in Haiti, and then take possession of Louisiana. ${ }^{20}$ However, virtually all of his army died of yellow fever or other tropical diseases while in the Caribbean, leaving him faced with the dilemma of trying to muster and transport another army. Instead, he ultimately decided to sell what his secret treaty had forbidden him to sell: thus was born Thomas Jefferson's Louisiana Purchase and the beginning of the evolution of Louisiana's civil law. ${ }^{21}$

\section{Moreau Lislet, Architect of the Louisiana Digest}

Louis Casimir Elisabeth Moreau Lislet was born in Dondon, St. Martin Parish, Saint Domingue (presently Haiti) in $1766 .{ }^{22}$ See Figure $1 .^{23}$ He studied law in Paris and received the title of "Avocat de Parlement" around 1788. Lislet married Anne Philippine de Peters in Paris in 1789 and they returned to Saint Domingue in $1790 .^{24}$

\section{A. Professional Experience}

Between 1790 and 1793 Moreau Lislet practiced law in Saint Domingue. After the slave uprising and revolutionary takeover of the island

and economic exigencies extant during the end of the Spanish colonial period in Louisiana.

${ }^{20}$ See, e.g., Herman, supra note 16; see also Henry J. Richardson III, Excluding Race Strategies from International Legal History: the Self-Executing Treaty Doctrine and the Southern Africa Tripartite Agreement, 45 VILL. L. REV. at 1103-1105 (2000) \& Roger K. Ward, The French Language in Louisiana Law and Legal Education: A Requiem, 57 LA. L. REV. 1283, 1289 (1997) for a discussion of this volatile transition.

${ }^{21}$ See Robert Knowles, The Balance of Forces and the Empire of Liberty: States' Rights and the Louisiana Purchase, 88 Iowa L. Rev. 343 (2003); See also, Roger K. Ward, The Louisiana Purchase, 50 LA. B.J. 331 (2003) at 333-334 for analyses and further citations documenting the factors leading up to Napoleon's decision to sell the Louisiana Territory.

${ }^{22}$ This simple declaratory statement is a virtual minefield of controversy. Moreau Lislet's date of birth has been often disputed, and the name given him at birth did not include the sobriquet "Lislet." However, thanks to Prof. Levasseur's diligent and thorough research, we can now make this assertion with a high degree of certainty. See generally ALAIN A. LEVASSEUR WITH VICENÇ FELIÚ, MOREAU LISLET: The MAN BehIND THE Digest of 1808 79-113, Claitor's Publishing Division, Baton Rouge 2008.

${ }^{23}$ All Figures referenced in this article are in an Appendix, in numerical order, following the conclusion of the article.

${ }^{24}$ Id. at $95-97$. 
by Toussaint Louverture in 1791, Moreau Lislet had the opportunity to become the attorney for many emigrants wishing to secure their property in their absence from Saint Domingue. The revolutionary events taking place in Saint Domingue after 1791 were the main factors in Moreau Lislet's emigration to Philadelphia with his family in 1793. The family returned to Saint Domingue a year later, and Moreau Lislet continued his practice, serving as public defender and judge on several occasions. ${ }^{25}$

This pattern of practice and public service continued until 1803 when, en route with his family to Cap Français for an official assignment, enemy ships forced the vessel in which he was traveling to divert to Santiago de Cuba. On October 18, 1803, Moreau Lislet's stay in Santiago became indefinite when the French evacuated Port-au-Prince, Haiti, preventing his return to his homeland. While in Santiago, Moreau Lislet continued to practice law and manage the affairs of his fellow émigrés through the agency of the French Government in that city. ${ }^{26}$

By August of 1804, the Moreau Lislet family joined the migration of French colonists from Saint Domingue to Louisiana, a move which marked the next stage in his career. During this period, Moreau Lislet not only became familiar with the English and Spanish languages, but he also studies the practice of law in a Spanish civil law jurisdiction (Cuba) and in a common law jurisdiction (United States), as he continued to manage émigré affairs for clients in both Philadelphia and Santiago de Cuba. ${ }^{27}$

\section{B. Drafting the Digest of THE CiviL LAWS Now IN FORCE IN THE TERRITORY OF ORLEANS (1808).}

Shortly after arriving in Louisiana, Moreau Lislet began to reestablish his career and his professional, social, and political positions in life. By February 4,1805 , when his name first appears in a joint resolution ${ }^{28}$ of the legislature of the Orleans Territory ${ }^{29}$ as a translator, he had already returned to

\footnotetext{
${ }^{25}$ Id. at $98-101$.

${ }^{26}$ Id. at 111-112.

${ }^{27}$ Id. at 113 .

${ }^{28}$ Joint resolution of the two chambers, signed by J. Poydras, President of the Council and approved by the governor, W.C.C. Claiborne on February the $4^{\text {th }} 1805$.

${ }^{29}$ The Territory of Orleans was the area of land transferred in the Louisiana Purchase of 1803 south of the $33^{\text {rd }}$ parallel that later became the state of Louisiana. See An Act: Erecting Louisiana into Two Territories, and Providing for the Temporary Government Thereof, 8 Cong. Ch. 38, 2 Stat. 283 (1804).
} 
public service. ${ }^{30}$ This appearance confirms that as early as 1805 Moreau Lislet was fluent enough in English to be appointed as an official translator. Moreau Lislet did not retain the position of translator for long, however, and by October of 1805 he had resigned to establish a law practice with Pierre Derbigny. Moreau Lislet's reputation as a fine attorney and legal scholar rose quickly in the Territory of Orleans. ${ }^{31}$

In May 1806, Governor William C.C. Claiborne, who had been appointed by Thomas Jefferson, vetoed a bill declaring which laws were in force in the territory. This provoked the Legislative Council to a adopt an eloquent Manifesto declaring the fierce attachment of Louisianans to the civil law of continental Europe. ${ }^{32}$ In June of the same year, the Governor approved a legislative resolution to appoint James Brown, a native of Virginia, and Louis Moreau Lislet to prepare a Civil Code for use in the Territory of Orleans. ${ }^{33}$ The mandate given the drafters (of what later became known as Louisiana's first civil code) was to make the civil law by which the territory was already governed the ground work of the new Code.

Although Brown was appointed as co-drafter of the Digest of 1808 alongside Moreau Lislet, legal scholarship today holds that the Digest of 1808 was almost entirely Moreau Lislet's work. ${ }^{34}$ See Figure 2.

The source of the continuing controversy is not the question of authorship, but rather the sources the authors used to compile the Digest. The joint chambers of the legislature charged the authors "to compile and prepare jointly, a Civil Code for the use of this territory. Resolved, that the two jurisconsults shall make the civil law by which this territory is now governed, the ground work of said code..." 35 Stated thus, the legislature's intent appears quite clear: to draft a digest of the law in force in the territory, which at that time was the Spanish civil law. ${ }^{36}$

${ }^{30}$ Levasseur, supra note 22 , at 115 .

${ }^{31}$ Id. at 116-117.

${ }^{32}$ Moreau Lislet \& Brown, supra note 4, at $49-53$.

331806 La. Acts $214-218$.

${ }^{34}$ Levasseur, supra note 22, at 167.

${ }^{35}$ Session Laws of American States and Territories, Territory of Orleans, 18041811. Legis: 1-1806, S.I. p. 215.

${ }^{36}$ Despite the unequivocal instructions, there is still a widely held belief that Moreau Lislet somehow ignored the legislature's specific charge and based the Digest of 1808 on the French Code Civil of 1804 and the French Project of the year VIII. Levasseur, supra, note 22 at 168 . However, comparing the Digest of 1808 and the work of Moreau Lislet shows that the Digest's foundations clearly emerge from 
To accomplish their assigned task the drafters needed a model of just what a civil code was. The drafters took as their model an official draft of a civil code for the French, known as the Projet of the Year VIII or the Projet du Gouvernement (1800). This draft had been proposed as a civil code for the French before Napoleon impressed his personality on the final French civil code. In Louisiana, the French Projet du Gourvernement became the interface between the information systems of Spanish law and Louisiana's first civil code, the Digest of $1808 .^{37}$

The effect of Napoleon's personality can be seen in the changes made in the text adopted during the proceedings of the Council of State. Napoleon played a very active part in these deliberations. One of the key traits of Napoleon's personality was his decisiveness. He was, it appears, impatient with debates about legal theory. ${ }^{38}$ Going into the debates before the Council of State, the text under consideration was an expression of natural law theory; this can be seen clearly in the preliminary articles of the Projet du Gouvernement. Coming out of the debates on the Projet was the Code Napoleon or Civil Code des Français (1804), from whose preliminary articles all express reference to legal theory had been stripped. ${ }^{39}$ It is pictured below at Figure 3.

Spanish civil law. See, e.g., Robert A. Pascal, Sources of the Digest of 1808: A Reply to Professor Batiza, 46 TUL. L. REV. 603 (1972).

${ }^{37}$ Fenet, RECUEIL COMPLET DES TRAVAuX PRÉPARATOIRES DU CODE CIVIL. ProjeT DE L'AN VIII, Vol. 2. (Paris 1836).

${ }^{38}$ On the 28th of Messidor, year 9 of the Republic, the Conseil d'État, presided over by Napoleon himself, peremptorily ordered that the Projet's Preliminary Title be redrafted. Unlike the actions taken with respect to other provisions of the Projet, no debate was recorded. In place of the first article of the Projet, which had expressly recognized natural law, the redraft presented on the 4th of Thermidor, year 9 , provided that the laws are executory in the whole Republic, fifteen days after the promulgation made by the First Consul (who was then Napoleon). PROCÈs-VERBAUX DE CONSEIL D'ÉTAT, YEARS IX AND X (Paris 1803). With these and other changes made by the redraft, law in general came to be interpreted as resting almost solely on the will of the legislator. While a theory of legal positivism was not expressly set forth in the Code Napoléon, one can be inferred from the changes made in the Preliminary Title by the redrafted final articles. Nevertheless other articles of the Code Napoléon, particularly in the law of obligations, were drawn from the natural law tradition, particularly as reflected in the writings of Domat and Pothier.

${ }^{39}$ Compare the Preliminary Title of the PROJET OF THE YEAR VIII, Fenet supra note 36 , with that of the CODE NAPOLEON (1804) itself. 
As Professor René David observes, the French codes were the product of the school of natural law. They were not formulated on the principle of the omnipotence of the legislator. The adoption of the French Codes, he notes, saw a complete reversal in outlook. "The codes desired by natural law theorists gave rise to a generation of positivists, who saw not only legislation but the law itself as a legislative creation." ${ }^{40}$ This theory did not prevail in Louisiana.

\section{Examination of Spanish Sources of Law}

Contrary to popular myth, Louisiana does not now have nor has it ever had the Code Napoléon as its law. As noted, Spanish law was imposed on the colony by the Spanish Governor, Don Alejandro O'Reilly, in 1769 in response to a rebellion against the Spanish crown. ${ }^{41}$ No change was made to the law in effect during the brief retrocession of Louisiana to France before France delivered it to the United States through the Louisiana Purchase. The Code Napoléon (1804) was not even published as a whole before the United States took possession of Louisiana in 1803. American dominion did not change the law in effect in Louisiana, except where Spanish law was deemed inconsistent with the U.S. Constitution. ${ }^{42}$

In 1806 , the legislature passed a bill to declare what law was in effect in the territory. ${ }^{43}$ The bill first stated that the Roman law of the Emperor Justinian, particularly as interpreted by the French commentator Domat, was in force except as derogated from by the Spanish law. See Figure 4. Second, the bill set forth what Spanish law was said to be in effect in the Territory:

1. The Recopilación de Castilla (1567 and 1777);

2. The Autos Acordados (1745);

3. Las Siete Partidas (the law of the Seven Parts drafted 1256-1263 under Alfonso the Wise but not promulgated as law until 1343);

4. The Fuero Real of Castile (1254, also under Alfonso the Wise);

5. The Recopilación de Leyes de los Reynos de las Indias (1661);

6. The Leyes de Toro (1505);

${ }^{40}$ RENÉ DAVID, FRENCH LAW: ITS STRUCTURE, SOURCES, AND METHODOLOGY 15 (1972).

${ }^{41}$ Don Alexander O'Reilly, Ordinances and Instructions of Don Alexander

O'Reilly in Ancient Jurisprudence of Louisiana, reprinted in 1(2) LA. L.J. 1 (1841).

See also text accompanying $n$. 10 supra.

${ }^{42}$ An Act: Further Providing for the Government of the Territory of Orleans, 8

Cong. Ch. 23, 2 Stat. 322 (1805).

${ }_{43}$ See Elizabeth Gaspar Brown, Legal Systems in Conflict: Orleans Territory 1804 - 1812, 1 AM. J. LEGAL HIST. 35, 47 - 48 (1957). 
7. The Royal Orders and Decrees which had formally been applied to Louisiana, all as aided by the authority of reputable commentators admitted in the courts of Justice.

These principal Spanish sources along with the Curia Philipica and Febrero Adicionado are found in three primary, contemporaneous Louisiana works: the de la Vergne volume of the Digest of 1808 (hereinafter the de la Vergne volume); $;^{44}$ an annotated first edition of the Digest of $1808 ;^{45}$ and the published inventory of Moreau- Lislet's possessions made shortly after his death. ${ }^{46}$ See Figures 5, 5.a, 5.b, 5.c, and 6. Therefore, an examination is

${ }^{44}$ The de la Vergne volume, a reprint of an original copy of the Digest of 1808 , is "bound with interleaves containing references in manuscript to various civil laws and commentaries. According to the preface to these manuscript annotations, the references opposite the English texts of the Digest are to various laws of civilian jurisdictions on the same subjects as the texts and those opposite the French texts are to the actual sources of the texts themselves. [See Figures 5 to 5.c]. These latter references are very predominantly to Spanish laws and works, even in those many instances in which it is obvious that the words of the particular texts were taken from the French Code Civil of 1804 or one of its projets. The annotations, therefore, lend support to the conclusion that the Digest was indeed in substance primarily a digest of the Spanish laws in force in the Territory of Orleans in 1808, even though the formal source of many of its provisions was the French Code Civil or one of its projets, and tend to refute the popular notion that the Digest represents an acceptance of French Law in what is now the State of Louisiana." A REPRINT OF MOREAU LISLET'S COPY OF A DIGEST OF THE LAWS NOW IN FORCE IN THE TERRITORY OF ORLEANS (1808) Preface to the Reprint (The Louisiana State University School of Law and the Tulane University School of Law 1968). It is believed that the annotations in the de la Vergne volume are a scrivener's copy of Moreau Lislet's notes made in his copy of the Digest of 1808. The de la Vergne volume is now available online at the LSU Civil Law Online page with the original annotations fully transcribed for ease of use at www.law.lsu.edu/digest.

${ }^{45}$ This annotated first edition Digest of 1808 , mentioned id., is the one discovered by Professor Robert Pascal, Professor Emeritus Paul M. Hebert Law Center, Louisiana State University, in 1965 in the Louisiana Room of the Louisiana State University Library. See Figure 2. It is presently located in the Hill Memorial Library of Louisiana State University and was made available for the original research in preparation of the symposium and for this article. We owe special thanks to Professor Pascal, who provided invaluable insight into the collection of original Louisiana documents, and who advised the organizers in the selection of panelists for this symposium.

${ }^{46}$ All the facsimiles of original documents pertaining to Moreau Lislet's life were gathered by Professor Alain Levasseur, Hermann Moyse, Sr. Professor of Law Paul M. Hebert Law Center, Louisiana State University during his research for his book LOUIS CASIMIR ELIZABETH MOREAU LISLET, FOSTER FATHER OF LOUISIANA CIVIL 
warranted of the relevant Spanish sources which influenced and factored into the formation and evolution of Louisiana civil law in the late 18th and early 19 th centuries.

\section{A. Las Siete Partidas}

Las Siete Partidas emerged from the landscape of medieval European codification as a unique code of civil law. ${ }^{47}$ See Figure 7. Certainly, there are other examples of legal collections contemporaneous to the Partidas, such asthe Constitutions of Melfi, De legibus et consuetudinibus Angliae, the Coutumes de Beauvaisis, and the statutes of Edward I Longshanks, but none approaches the depth and level of organization of the Partidas. ${ }^{48}$ Both a legal encyclopedia and a codification rolled into one, the Partidas was intended as a code of law for the whole kingdom. ${ }^{49}$ It is a true code, following the model of Justinian's Corpus Iuris Civilis; ${ }^{50}$ it is comprehensively and systematically organized in books, titles and laws. ${ }^{51}$ The Partidas were composed between 1256 and 1265 during the reign of King Alfonso X, the Wise (reign: 12521284), but may not have been known by its present name during his life. ${ }^{52}$

Las Siete Partidas is named for the work's division into seven parts, following the format of the Corpus Iuris Civilis and honoring the importance

LAW (The Louisiana State University Law Center Publications Institute 1996, revised and reissued in 2008 as MOREAU LISLET: THE MAN BEHIND THE DIGEST OF 1808, Claitor's Publishing Division, Baton Rouge). Professor Levasseur's research in original materials from such diverse sources as the French National Archives, the New Orleans Notarial Archives, and even the parish records of Dondon, Haiti, where Moreau Lislet was born, has resulted in a collection of facsimile materials spanning and documenting the life of Moreau Lislet which is presently held in the Rare Book Collection of the Paul M. Hebert Law Center Law Library. His original research is one of the cornerstones supporting the argument for Spanish law as the primary substance of the Digest of 1808 .

${ }^{47}$ Joseph F. O'Callaghan, Alfonso $X$ and the Partidas in 1 LAS SIETE

PARTIDAS xxx (Robert I. Burns, S.J. ed., Samuel Parsons Scott trans., University of Pennsylvania Press, 2001).

${ }^{48} \mathrm{Id}$.

${ }^{49}$ E. N. VAN KLEFFENS, HisPanic LAW UNTIL the END OF THE MidDle AgES 155

(Edinburgh University Press 1968).

${ }^{50}$ CORPUS IURIS CIVILIS (Theodore Mommsen et al. eds., Weidman, 19151928).

${ }^{51}$ O'CALLAGHAN, supra note 46.

${ }^{52}$ In his last will, dated 10 January 1284, Alfonso refers to the book as the Setenario and in other documents it has been referred to as the Libro de las Leyes or Book of Laws. Id. at xxxvi. 
given to the number seven in the XIII and XIV centuries. ${ }^{53}$ Authorship is credited to Alfonso $\mathrm{X}$ in the prologue of the work, and each letter of Alfonso's name is ingeniously used in the initial letter of each section to reinforce the notion of his authorship. ${ }^{54}$ In reality, it is more likely that a team of legal scholars composed this work, including Fernando Martínez de Zamora, Maestre Roldán, and Jacobo de las Leyes. ${ }^{55}$ The Partidas remained the effective law in Iberia until the end of the $19^{\text {th }}$ century and in Latin America until the middle of the $20^{\text {th }}$ century; it still influences present day law in both regions as well as in the southern United States. ${ }^{56}$

\section{B. La Recopilación de Castilla}

In the Partidas, Alfonso $\mathrm{X}$ began a codification effort with the intent of unifying and simplifying the legal landscape in his kingdoms. At this time, the kingdoms of Castile and León were two distinct legally entities governed by one king, Alfonso X. He aimed to abrogate the old laws of his kingdoms and replace them with a set of comprehensive laws, La Recopilación de Castilla. $^{57}$ See Figure 8 . He failed in this initial attempt because his son and his subjects were very protective of their old rights and liberal prerogatives. They actively opposed his reforms in order to maintain their traditional laws, which provided them much more freedom to act for their own benefit rather than for the greater good. ${ }^{58}$

${ }^{53}$ To this day, we see the evidence of this emphasis in aggregations such as the Seven Liberal Arts, the Seven Sacraments, the Seven Gifts of the Holy Spirit, the Seven Capital Sins, the Seven Joys and Sorrows of the Virgin Mary, the Seven Ages of Man, etc.

${ }^{54}$ Each section of the Partidas begins in this manner, forming the name Alfonso;

I. A seruicio de Dios

II. La ffe cathólica

III. Fizo Nuestro Sennor Dios

IV. Onras sennaladas

V. Nascen entre los ommes

VI. Sesudamente dixeron

VII. Oliuidança et atreuimento

Castile (Kingdom) \& Alfonso X, LAS SIETE PARTIDAS (Gregorio Lopez ed., Madrid, 1789) (1254 - 1282).

${ }^{55}$ O'CALLAGHAN, supra note 46 , at xxxvii.

${ }^{56}$ VAN KLEFFENS, supra note 48, at 164; See also Summa Corp. v. California, 466 U.S. 198 (1984).

${ }^{57}$ VAN KLEFFENS, supra note 48, at 226.

${ }^{58}$ Id. at 212-3. 
After his death, the traditional laws or fueros returned to force in conjunction with the Partidas, but the appeal of a consolidated Roman law to rule the kingdoms did not die with Alfonso X. His great-grandson, Alfonso XI (reign: 1312-1350), recognized that the solution was not to abrogate the old laws but to compile and classify them, giving preferential treatment to some norms over others. ${ }^{59}$ This system became characteristic of Spanish law as the method of recopilación, that is a collection of legal texts in force that are classified by priority or weight of authority. ${ }^{60}$ In Castile these recopilaciones were the Leyes de Toro (1505), the Nueva Recopilación (1567), and the Novísima Recopilación (1805). ${ }^{61}$ See Figures 9 and 10. At the time of Spanish rule in the Territory of Orleans (1769-1803), the former two were in effect in both Spain and Louisiana.

\section{Recopilación de Leyes de los Reinos de las Indias}

As the conquest of the Americas was primarily a Castilian enterprise, ${ }^{62}$ the Castilian recopilaciones came into effect in their overseas possessions, ${ }^{63}$ just as the French had brought the Coutume de Paris as the principal law in their possessions. In 1528, the ordinances of the Audiencia de La Hispaniola decreed that Castilian law was to be followed in conformity with the Leyes de Toro of $1505 .{ }^{64}$ This enactment, repeated in other audiencias throughout the New World, ensured that the system of recopilaciones would be in force. This led to the creation of the Recopilacion de Leyes de los Reynos de las Indias (1680), a collection of pre-existing laws to be followed in the Castilian overseas colonies and the primary source of Spanish colonial law. ${ }^{65}$ See Figure 11.

${ }^{59}$ Id. at 226.

${ }^{60} \mathrm{Id}$. at 227 . Recopilación is a collection of texts rather than a codification into a single text.

${ }^{61}$ Id. at 227, n. 2. The Novissima Recopilación is not mentioned at length because, as noted, it did not begin publication until 1805, after the Spanish lost dominion over Louisiana. It was later cited, however, by Louisiana courts. See, e.g., Succession of Dill, 155 La. 47 (La. 1923).

${ }^{62}$ The Papal Bull Inter Caetera issued by Alexander VI on 4 May 1493 granted the newly "discovered" lands of the Americas as conjugal property of King Ferrán of Aragon and Queen Isabel of Castile during their lifetimes but these lands were to pass to the Kingdoms of Castile and León on the death of either partner.

${ }^{63}$ VAN KLEFFENS, supra note 48, at 235.

${ }^{64}$ Id. at 263.

${ }^{65}$ Id. The Spanish audiencias were originally high courts of appeal that became, in effect, general administrative boards for regions within colonial territories. 


\section{El Fuero Real de Castilla}

The fueros are a typical Iberian institution combining ancient customary law, traditional law, and special regional and local charters that governed the legal picture in localized areas throughout the peninsula. ${ }^{66}$ See Figure 12. Over time, the term fuero acquired several meanings: charters given by the king for the governance of townships, special statutes granted to social groups or institutions, and sets of laws of general application to the kingdom. ${ }^{67}$

The proliferation of the fueros after the fall of the Visigothic Kingdom in 711 created a situation ripe for conflicting sets of law. ${ }^{68}$ Although Alfonso X had the Fuero Real created in 1255 in an initial attempt to unify the laws of his kingdoms, the Fuero Real is by no means an exhaustive codification, with subject matter and provisions that derive from the Fuero Juzgo (the law of the Visigothic kingdom based on the Roman ius commune), Castilian local fueros, customary law, and vestigial elements of Roman law. ${ }^{69}$ After Alfonso X's not entirely successful attempt to replace the Fuero Real with the Partidas, the Fuero Real remained in effect along with the Partidas and was incorporated into the general law through the system of recopilaciones. ${ }^{70}$

\section{E. Curia Philipica}

The Curia Philipica is the work of Juan de Hevia Bolaños, an Asturian legal scholar who worked in Latin America during the first half of the $17^{\text {th }}$ century. First published in Lima in 1603, the Curia quickly gained a reputation as a complete reference source. ${ }^{71}$ See Figure 13.

The Curia served as a basic legal text book in Latin American law schools until the beginning of the $20^{\text {th }}$ century. However, in the context of the present inquiry, its most significant use was as a guide for practitioners on the interpretation and practical application of the fueros, Partidas, and recopilaciones. ${ }^{72}$

\section{${ }^{66}$ Id. at 18.}

${ }^{67}$ Id. at 125.

${ }^{68}$ Id. at $135-44$.

${ }^{69}$ Id. at $167-8$.

${ }^{70}$ See generally JAVIER BARRIENTOS GRANDON, LA CULTURA JURÍDICA EN LA NuEva ESPAÑa 16-37 (Universidad Autonoma de México 1993).

${ }^{71}$ Id. at 100.

${ }^{72} \mathrm{Id}$. 


\section{F. Febrero Adicionado}

José Febrero, Royal Notary, wrote a practical guide in 1769 now known as the Febrero Adicionado (or simply Febrero). See Figure 14. It is a practice and procedure guide that was intended for use by practitioners in the application of Spanish civil law. Febrero's work quickly gained wide acceptance and was often reprinted with additional material to reflect evolving interpretations of the law, hence the title adicionado. ${ }^{73}$ The Febrero continued to serve as a reference source and practice guide in Spain and its former colonies, while the fueros, Partidas, and recopilaciones held their position of primacy in Spanish law. ${ }^{74}$

\section{The Legacy of Louis Moreau Lislet}

Louis Moreau Lislet used Spanish civil law as a fundamental basis to create the beginnings of Louisiana civil law. This is apparent when analyzing the laws of the Digest of 1808 as applied and interpreted in $19^{\text {th }}$ and $20^{\text {th }}$ century jurisprudence.

\section{A. Deciphering, Comparing \& Analyzing legal texts}

The relationship between the Digest of 1808, the French Projet du Gouvernment, and the Spanish recopilaciones is a complex one. For example, the de la Vergne volume has handwritten notes, dated 1814, attributed to Moreau Lislet. ${ }^{75}$ As previously observed, the Foreword to this volume explains that the volume itself contains notes on the interleafs, between the English and French legal texts, and that the sources of the Louisiana provisions of law are found in these notes on the pages opposite the relevant French text. ${ }^{76}$ Thus, one can compare, for example, the third article of the Digest of 1808, the corresponding article in the French Projet du Gouvernement, and the law given as the source of the provision of the Louisiana Digest of 1808 as later translated by Moreau Lislet and Henry

${ }^{73}$ Adicionado is the past participle of the verb adicionar, which translates into English as "to add to." Hence, adicionado can be accurately translated as meaning "added" [in the sense of material included].

${ }^{74}$ See generally MANUEL MATo Vizoso, BIOGRAFía DE D. JosÉ FEBRERo 39-50 (Imprenta de la Diputación Provincial, Lugo 1897).

${ }^{75}$ Moreau Lislet supra note 43.

${ }^{76}$ See id. for a description of these annotations. 
Carleton in the Laws of Las Siete Partidas which are Still in Force in the State of Louisiana ${ }^{77}$ as follows:

Louisiana Digest of 1808, Article 3:

Customs result from a long series of actions constantly repeated, which have by such repetition, and by uninterrupted acquiescence, acquired the force of a tacit and common consent.

French Projet du Gouvernement, Title 1, Article 5:

Custom results from a long series of actions constantly repeated which have acquired the force of a tacit and common agreement.

\section{Spanish Las Siete Partidas, Part 1, Title 2, Law 4:}

Custom (Costumbre) is an unwritten law, established by usage during a long space of time, in relation to those things which give rise to it....

The wording of the French and Louisiana provisions are more similar to each other than either are to the Spanish provision. All three, however, express the same legal principle. The use of the French Projet by the redactors of the Digest of 1808 can be compared to an attorney's use of a form book. The Projet's statements were adopted when they seemed conformable to Spanish law, and its statements were modified, where necessary, to reflect Spanish law or when "alterations and amendments" of the Spanish law were appropriate. $^{78}$

After its adoption, the Louisiana courts interpreted the Digest of 1808 as a kind of restatement of the Spanish law which had been in effect upon the

\footnotetext{
${ }^{77}$ Louis Moreau Lislet and Henry CARLETON, The LAWS OF LAS SiETE PARTIDAS, WHICH ARE STILl IN FORCE IN THE STATE OF LOUISIANA (New Orleans, James M'Karaher 1820). See Figure 15.

${ }^{78}$ For example, the Digest of 1808 reflected the Spanish law of a community of gains encompassing property acquired under onerous title (i.e. that property not acquired by donation or inheritance). Unlike the French law, the Louisiana and Spanish law did not provide for a community of movables. On the other hand the Digest of 1808 reflects concepts that the French had adopted, such as the limitation of the right to rescind a grossly unbalanced contract for lesion to the seller of immovable property. This approach is arguably better adapted to the needs of a modern commercial republic for certainty in transactions than the broader medieval remedy for lesion, extending to buyer and movable property, found in the Spanish laws of Las Siete Partidas. Conclusion of William Tête, delivered in "A Closer Look: Uncovering the Spanish Roots of the Louisiana Civil Law," Annual Meeting of American Association of Law Libraries (17 July 2007).
} 
cession of Louisiana to the United States. For example, in 1817 the Louisiana Supreme Court in Cottin v. Cottin ${ }^{79}$ applied the Recopilación de Castilla to require that a child live twenty-four hours after birth to be deemed viable and capable of inheriting. The decision is significant in holding that a provision of Spanish law not included in the Digest should nonetheless be applied where it is not inconsistent with the Digest.

Legal historian Richard Holcombe Kilbourne, Jr. observes:

In the years following. Cottin the jurisprudence reiterated that the Spanish law was Louisiana's common law, and continued to recognize the Digest as a kind of restatement of the essential principles of the law, its various titles and article serving at most merely as points of departure for lengthy expositions of Spanish and Roman law. ${ }^{80}$

The legacy of the Digest did indeed continue to exert authority for years to come.

\section{B. Moving forward}

In 1819, the Legislature appointed Moreau Lislet and Carleton to prepare a translation of The Laws of Las Siete Partidas, which are Still in Force in the State of Louisiana (1820). ${ }^{81}$ However, the translators reported that it was impossible in many cases to determine which laws are still in effect and that the question should be left to the determination of the judiciary. ${ }^{82}$ The translators' Preface sets forth the hierarchy of authority of the various Spanish laws, which accords a lower place to Las Siete Partidas than to other laws. ${ }^{83}$

In 1822, the Louisiana Legislature appointed Louis Moreau Lislet, Edward Livingston and Pierre Derbigny to revise what was called by then the Civil Code of 1808 and charged them to propose amendments in such a

${ }^{79}$ Cottin v. Cottin, 5 Mart. (o.s.) 93 (La. 1817).

${ }^{80}$ RiCHARD HOLCOMBE KILBOURNE, JR., A History OF THE LOUISIANA CIVIL CODE: THE FORMATIVE YEARS, 1803 - 1839 at 69 (1987).

${ }^{81}$ An Act to authorize and encourage the translation of such part of the Partidas as are considered to have the force of law in this state, approved March 3, 1819. 1819 La. Acts 44.

${ }_{82}^{8} \mathrm{O}^{\prime}$ Callaghan, supra note 46 , at xxiv.

${ }^{83}$ Id. at xvi. Highest in this hierarchy was the Recopilación de Castilla, followed by the Fuero Real, and then finally Las Siete Partidas at the bottom. 
manner as they saw fit. ${ }^{84}$ Their Preliminary Report reflects their intent to place strict limits on the authority of judges to interpret the written law. Though they proposed to give the judge authority to appeal to the dictates of natural equity in doubtful cases, they also proposed to require a judge to report to the legislature the cases where the judge exercised that authority, and that those decisions would have no effect as precedent unless approved by the legislature. ${ }^{85}$

Consistent with this approach, the Projet, which was the official draft of the Civil Code of 1825, recommended suppressing Article 3 of the Digest of 1808: "To say that customs have the force of laws in a country, where all the laws are written, appears to us to be a contradiction." 86 This recommendation was rejected. No system of legislative referral was adopted.

Professor John Henry Merryman observes that the French codification sought to make the law judge-proof. ${ }^{87}$ There is no evidence of such an effort in the preparation of the first Louisiana civil code, the Digest of 1808; its purpose was to preserve the civil law in effect against the pressure of the common law. There is, however, evidence of such an anti-judicial effort in the preparation of the Louisiana Projet of the Civil Code of 1825: in rejecting the elimination of Article 3, proposed on the basis that Louisiana would be a land where all the laws were written, Louisiana rejected the notion of the legislative omnipotence. ${ }^{88}$

Article 3521 of the Louisiana Civil Code of 1825 provided that "the Spanish, Roman and French laws, which were in force in this State, when Louisiana was ceded to the United States are hereby repealed in every case, for which it has been especially provided in this Code... ${ }^{189}$ Notwithstanding this provision, Louisiana courts continued to apply Spanish law in cases

${ }^{84} 1823$ La. Acts 68.

${ }^{85}$ Louis Moreau Lislet, Edward Livingston \& Pierre Derbigny, Preliminary Report of the Code Commissioners in A REPUBLICATION OF THE PROJET OF THE CIVIL CODE OF LOUISIANA OF 1825, lxxxv-xcv (Louisiana Legal Archives: New Orleans, 1937).

${ }^{86}$ A REPUBLICATION OF THE PROJET OF THE CIVIL CODE OF LOUISIANA OF 1825, 1 (Louisiana Legal Archives: New Orleans, 1937) (hereinafter, referred to as the Projet of the Civil Code of 1825) (1937). See Figure 16.

87 John Henry Merryman, The French Deviation, 44 AM. J. COMP. L. 109 (1996).

88 Tête, supra note 77 .

${ }^{89}$ LOUIS MOREAU LiSLET, EDWARd LiVINGSTON, P. DERBIGNY \& B. F. BUTLER, CIVIL CODE OF THE STATE OF Louisiana 1112 (English) - 1113 (French) (New Orleans, J. C. de St. Romes 1825). 
where it was deemed appropriate. Finally the Legislature in 1828 passed a statute abrogating "all the civil laws which were in force before the promulgation of the Civil Code lately promulgated..."

Spanish law had contributed to the viability of the Louisiana civil law by providing a basis for decisions in matters of civil law where Louisiana's codes left doubt as to which legal rule applied. However, after 1828 the emphasis shifted from the actual application of Spanish law to its use as an aid in interpretation. It is evident that the Louisiana judiciary was very wary of the idea that all civil law could be reduced to a civil code. Their judicial decisions also provided an official history of the role of Spanish law in Louisiana.

\section{Twentieth century debate}

In the late 1960's and early 1970's legal scholars became aware of the de la Vergne volume of the Digest of $1808 .^{91}$ However, Professor Rodolfo Batiza of Tulane challenged the accuracy of attribution of sources to Spanish and Roman law by examining how sentences or phrases in the French text of the Louisiana Digest of 1808 corresponded with the text of comparable French legal works. He concluded that the "actual sources" of the Louisiana Digest of 1808 were overwhelmingly French. He denied that the sources of that Digest of 1808 listed in the de la Vergne volume were actual sources. ${ }^{92}$ Professor Batiza's view quickly drew a reply from Professor Robert Pascal at Louisiana State University, who defended the de la Vergne volume's identification of Roman and Spanish law as the actual sources of the Digest of $1808^{93}$

At the time the Pascal-Batiza controversy arose, Louisiana was still using the Revised Civil Code of 1870, whose roots could be traced back to the Digest of 1808 . The controversy at the time was not only a matter of legal history, but also a question of how the Louisiana Revised Civil Code of 1870 should be interpreted and applied. Professor Pascal based his interpretation in:

1) the declaration in the de la Vergne volume of what the notes in it contain;

${ }^{90} 25^{\text {th }}$ Section of Act of $25^{\text {th }}$ March, 1828 , LOUISIANA SUPREME COURT, REPORTS OF CASES ARGUED AND DETERMINED IN THE SUPREME COURT OF LOUISIANA 383 (1859).

${ }_{91}^{91}$ Moreau Lislet, supra note 43.

${ }^{92}$ Batiza, supra, n. 3.

${ }^{93}$ Pascal, supra note 3. 
2) the legislature's mandate to Moreau Lislet and Brown to base the proposed civil code on the law still in effect in the Territory of Orleans;

3) the presumption that the drafters of the 1808 work adhered to their mandate;

4) the very title of the 1808 work as A Digest of the Civil Laws now in force in the Territory of Orleans; and,

5) the consistent early jurisprudence recognizing the Spanish law as being in effect in Louisiana even after it became a state of the American union.

On these bases, Professor Pascal's interpretation appears to be an exact and correct statement of the de la Vergne volume's provenance. ${ }^{94}$

Later historical developments, however, fed into the theory of the French origin of substantive Louisiana law, covering up its Spanish roots. Louisiana was hungry for scholarly doctrine to guide the application of its civil codes. The French language was more widely known in Louisiana than the Spanish. Though Spanish law was cited and used in its preparation, the draft or Projet of the Louisiana Civil Code of 1825 also borrowed heavily from French commentators, particularly Toullier on Obligations. ${ }^{95}$

Even as French was dying out as a literary language in Louisiana, it was retained as a second language of law. Louisiana jurists had easier access to French doctrine than to Spanish. Such doctrine became available to lawyers generally as it was included in judicial decisions. The legal treatises that Louisiana chose to translate were French, not Spanish. The popular belief that the Louisiana Civil Code derived from the Code Napoléon was so strong that the Legislature appropriated money for research on that assumption. When the compiled edition of the Louisiana Civil Code was prepared, provisions of the French Projet of the Year VIII were only included if they were closer to the Louisiana civil codes than was the Code Napoléon. Where the texts of the Code Napoléon and the Projet of the Year VIII may have been substantially the same, only the text of the Code Napoléon was given. This methodology discounted the importance of the Projet of the Year VIII. ${ }^{96}$

94 Tête, supra note 77.

${ }^{95}$ Charles Bonaventure Marie Toullier, Le Droit Civil Français SUIVANT L'ORDRE DU CODE: OUVRAGE DANS LEQUEL ON A TACHÉ DE RÉNUIR LA THÉORIE A LA PRATIQUE, vol. VI - X ( $5^{\text {th }}$ Ed. Paris: Jules Renouard, 1828-1843).

${ }^{96}$ Tête, supra note 77 . 


\section{Conclusion}

Since the time of the Batiza-Pascal controversy, the Louisiana Civil Code has undergone extensive revision. It can no longer be described as a 19th century civil code. In the process of revision, the drafters of the latest revisions of the Louisiana Civil Code have by preference drawn heavily on French sources, also perhaps on German legal theory, but not on Spanish sources. Some recourse could possibly be had to the Partidas and Domat, which are based in Roman law, on the theory that the drafters of the Digest of 1808 held that these works contained principles of natural law. But the drafters of the recent revisions have removed the term "natural law" from the preliminary title and substituted the term "justice." The term "justice" implies more discretion than the term "natural law," which was described by jurists in the early 19 th century as binding in conscience. ${ }^{97}$

In sum, Spanish law clearly formed an important part of Louisiana legal history. Despite an apparent preference to acknowledge French influence, Spanish law filled a gap between high hopes for a civil code and the reality of the needs for supplemental authority in the application of the law. If it had not been for recognition of the Spanish roots of Louisiana civil law in the early 19 th century, the civil law might not have survived in Louisiana. $^{98}$

Moreover, the mixture of legal traditions that has shaped Louisiana jurisprudence reflects two critical elements in the development of law and society in that state as well as the United States of America at large. First, Louisiana exemplifies the evolution of law through accretion and recopilación, where the Anglo-American common legal tradition is layered upon existing civilian jurisprudence, as occurred throughout the southern and western States, from Florida through Texas to California, and, most significantly for the purposes of this paper, Louisiana. Moreover, this evolution echoes a larger theme inherent to the American spirit: the notion of the "melting pot" that has so thoroughly penetrated the collective consciousness of the nation as to reify this consciousness. Just as individuals have come to the United States for hundreds of years in search of opportunity, freedom, and prosperity, so, too, have these individuals brought their legal traditions. The end result is a mixture of legal traditions reflecting the very mixture of cultures that our nation hosts. In a very real way, the most

\footnotetext{
${ }^{97} \mathrm{Id}$.

${ }^{98} \mathrm{Id}$.
} 
"American" aspect of the Louisiana civil law could be the accretive nature of its evolution.

\section{Appendix}

Fig. 1. Moreau Lislet

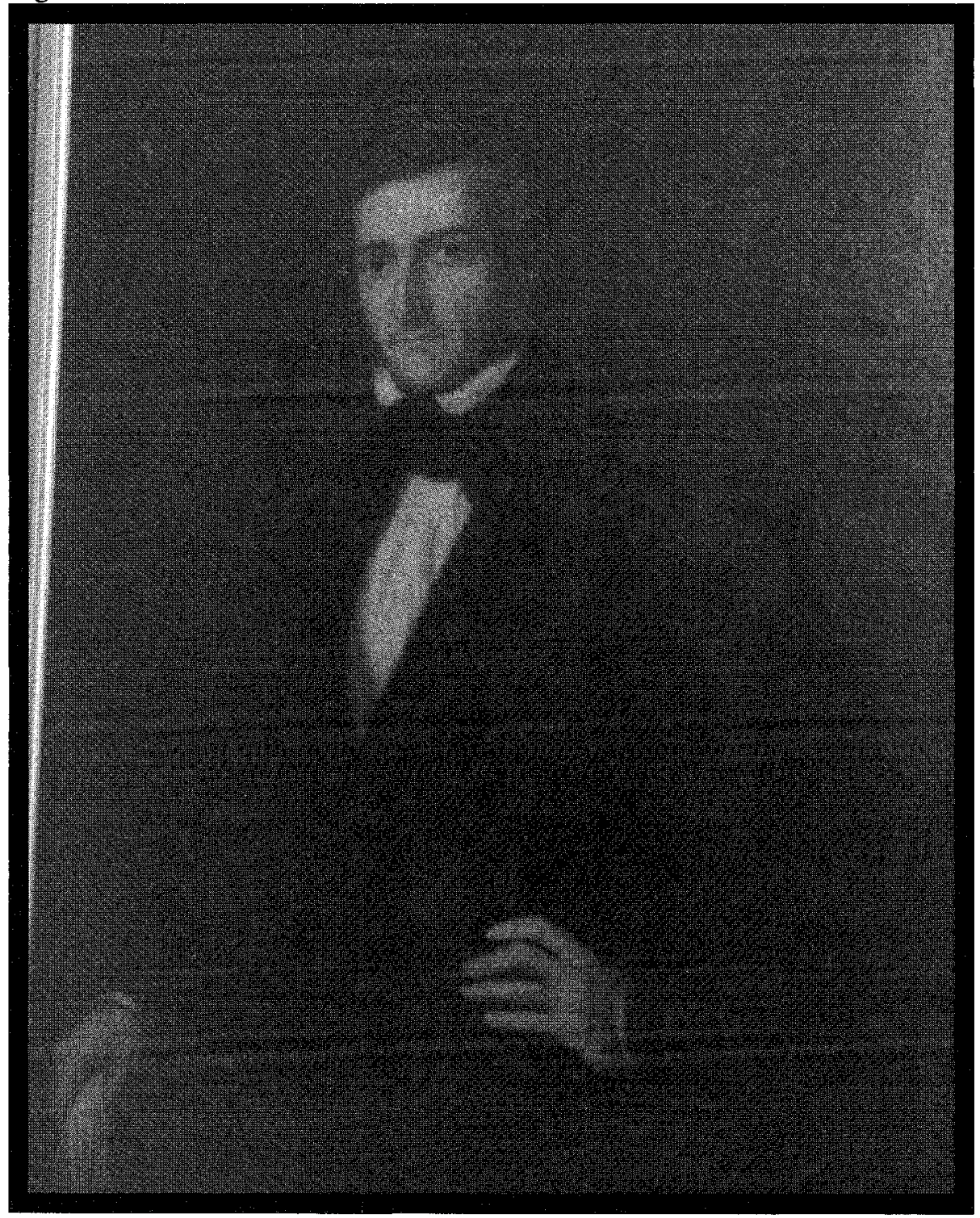


Fig. 2 - Title page of annotated first edition of the Digest of 1808, in Moreau Lislet's hand and bearing his signature at the top of the page, held by the Hill Memorial Library of Louisiana State University.

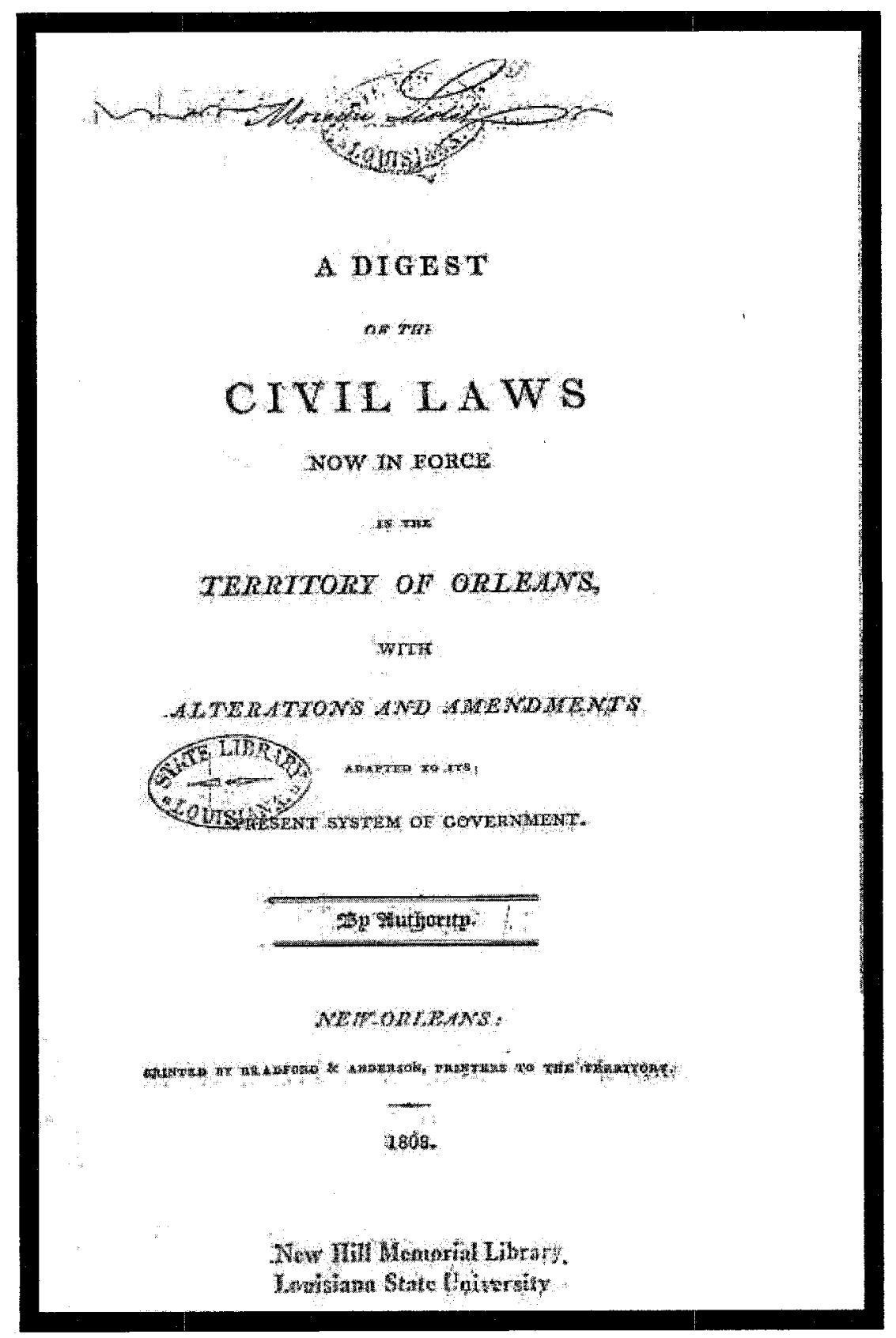


Fig. 3. Code Napoléon - Code Civil des Français (Paris, 1804). Photograph by Teresa M. Miguel. This book is held in the Rare Book Room of the Lillian Goldman Law Library, Yale Law School.

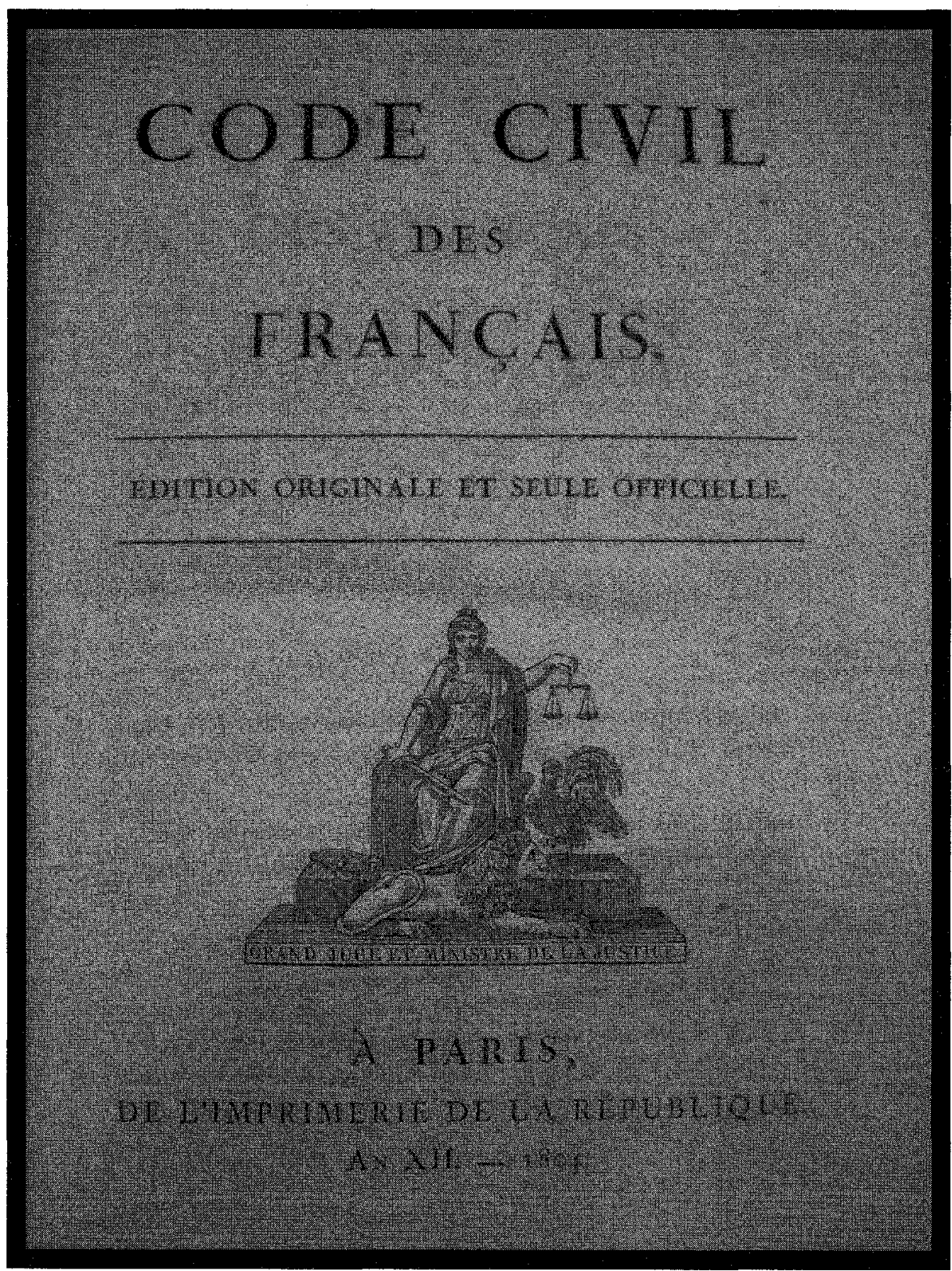


Figure 4. Jean Domat, The Civil Law in Its Natural Order (translated by William Strahan, Cushing Edition, 1850) 1694 - 1696. Photograph by Teresa M. Miguel. This book is held in the Rare Book Room of the Lillian Goldman Law Library, Yale Law School.

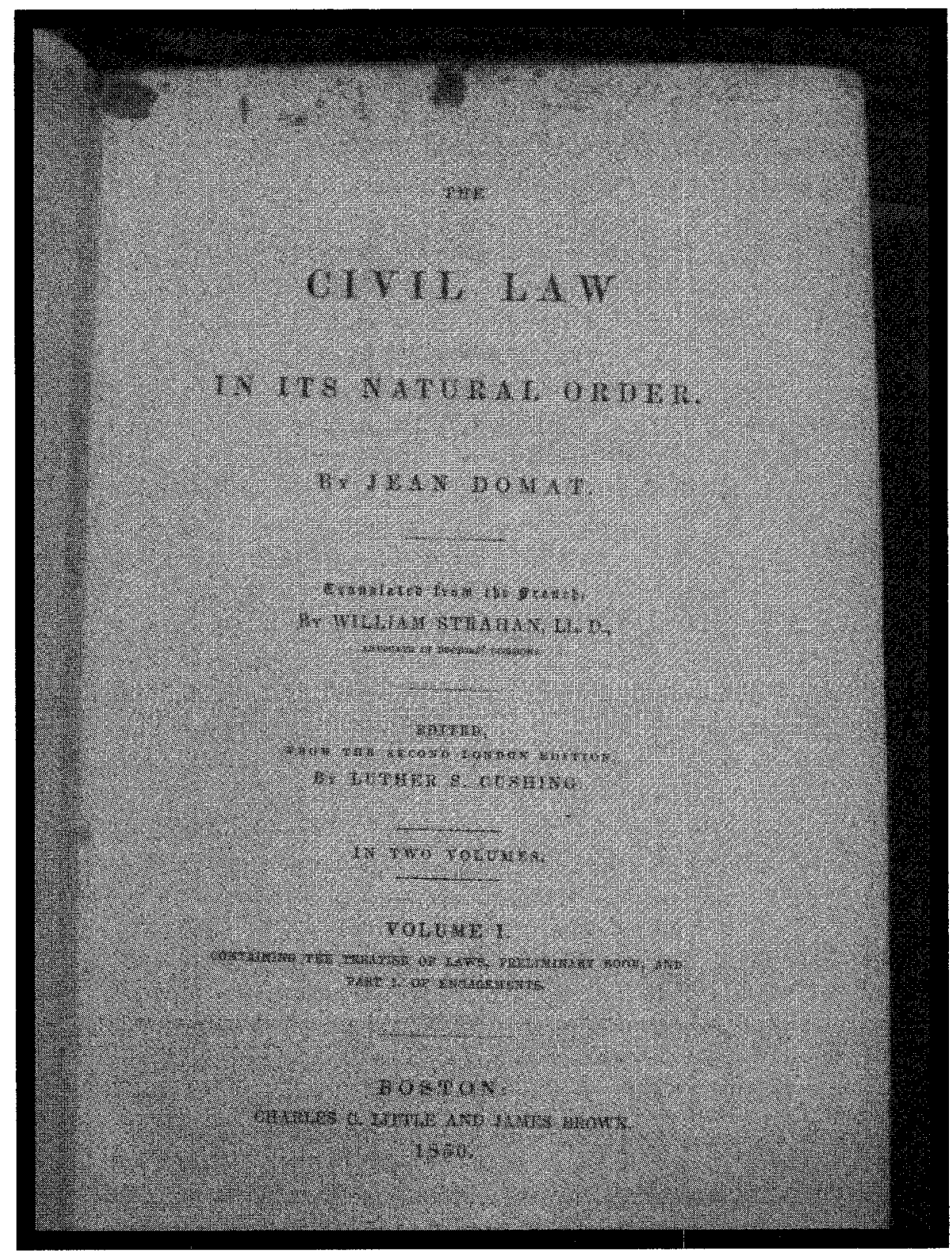


Fig. 5.1 Louis Moreau Lislet, A Digest of the Civil Laws Now in Force in the Territory of Orleans (1808); Containing Manuscript References to its Sources and Other Civil Laws on the Same Subjects (the "De La Vergne Volume") (photo. reprint of Moreau Lislet's copy, Baton Rouge, Louisiana State University 1968) (1808). Photograph by Teresa M. Miguel. This book is held in the Rare Book Room of the Lillian Goldman Law Library, Yale Law School.

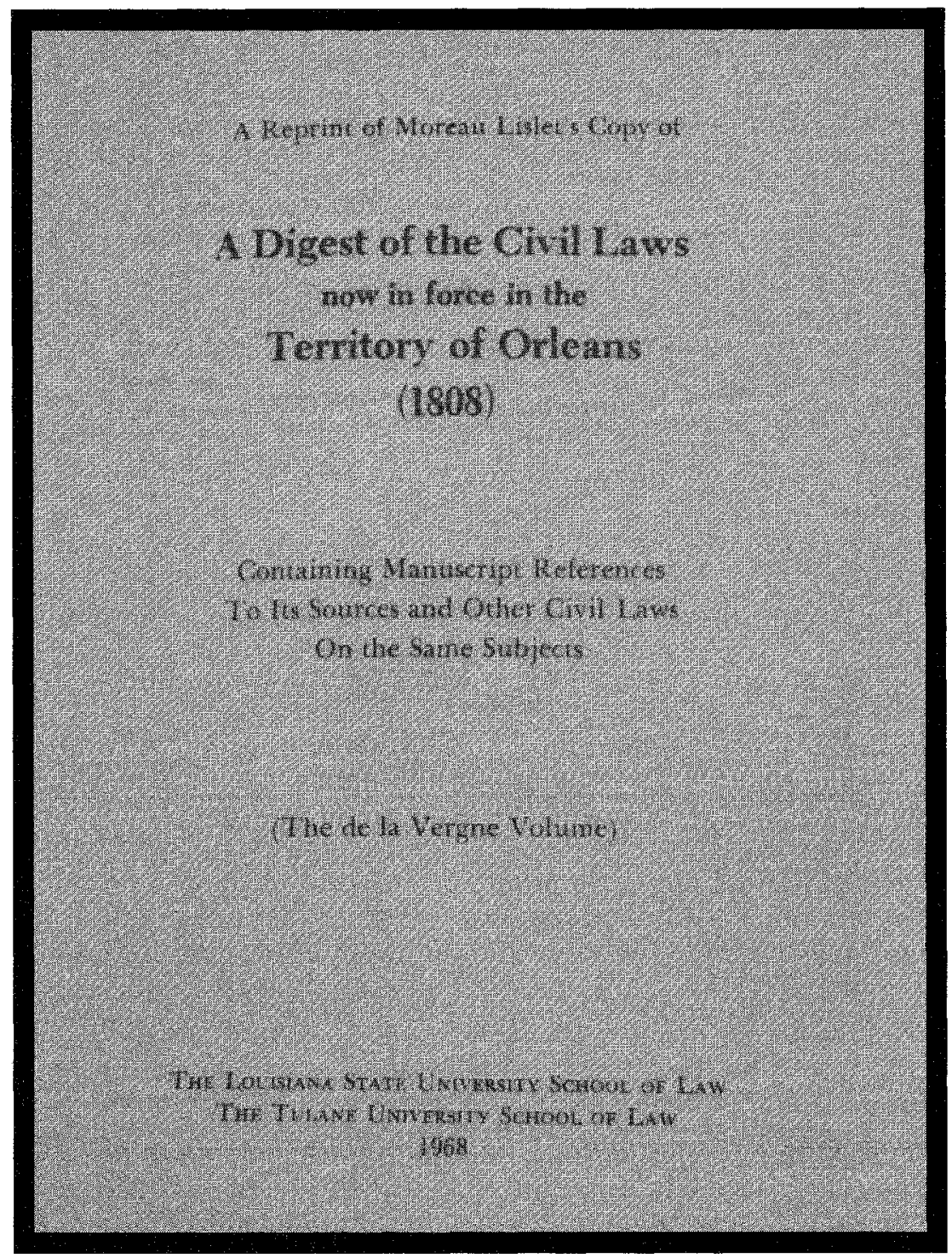


Fig. 5.2. Louis Moreau Lislet, A Digest of the Civil Laws Now in Force in the Territory of Orleans (1808); Containing Manuscript References to its Sources and Other Civil Laws on the Same Subjects (the "De La Vergne Volume") (photo. reprint of De La Vergne Volume, Baton Rouge, Louisiana State University 1968) (1808). Photograph by Teresa M. Miguel. This book is held in the Rare Book Room of the Lillian Goldman Law Library, Yale Law School.

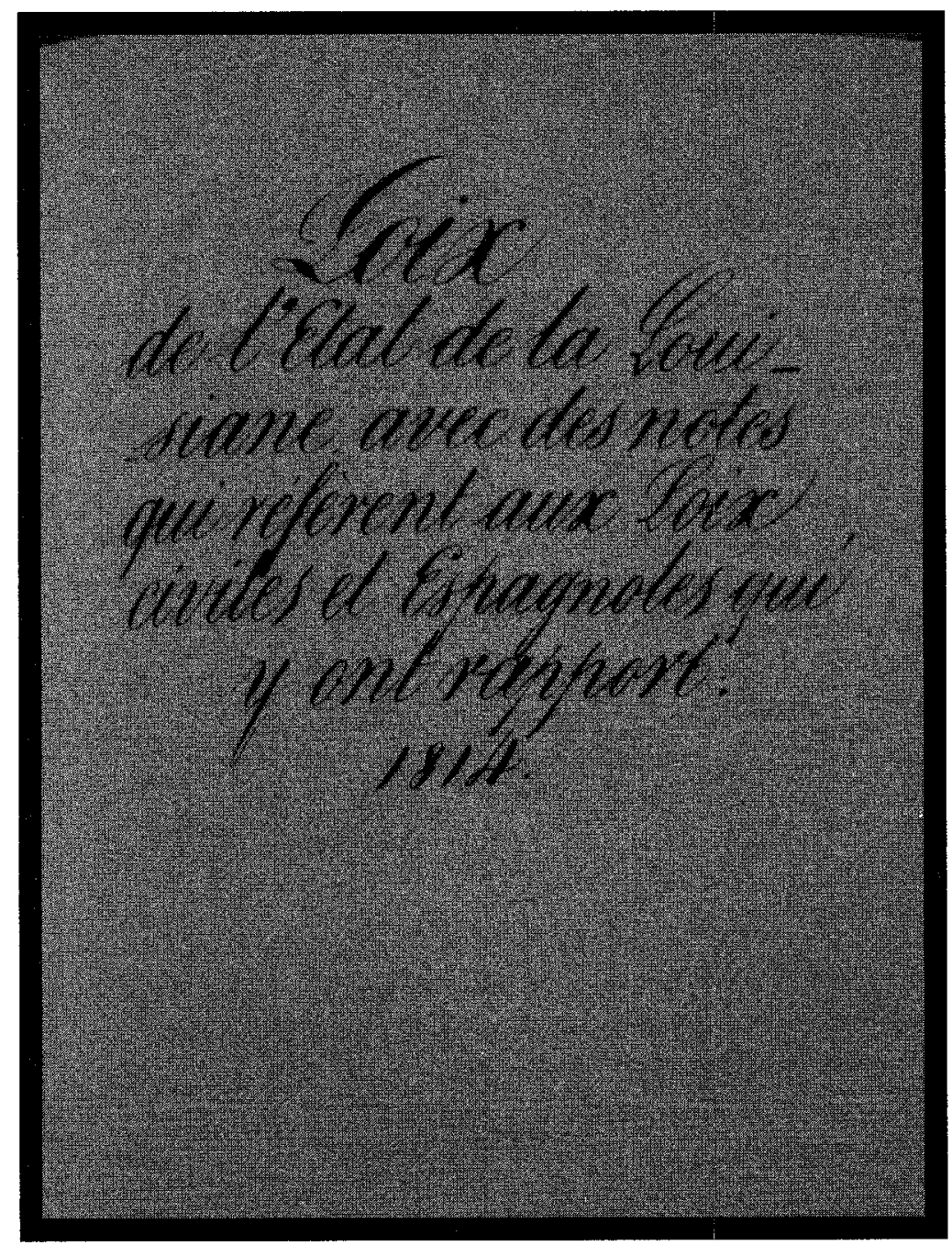

"Laws of the state of Louisiana with notes which refer to the civil and Spanish laws relative to them. 1814." 
Fig. 5.3. Louis Moreau Lislet, A Digest of the Civil Laws Now in Force in the Territory of Orleans (1808); Containing Manuscript References to its Sources and Other Civil Laws on the Same Subjects (the "De La Vergne Volume") (photo. reprint of De La Vergne Volume, Baton Rouge, Louisiana State University 1968) (1808). Photograph by Teresa M. Miguel. This book is held in the Rare Book Room of the Lillian Goldman Law Library, Yale Law School.

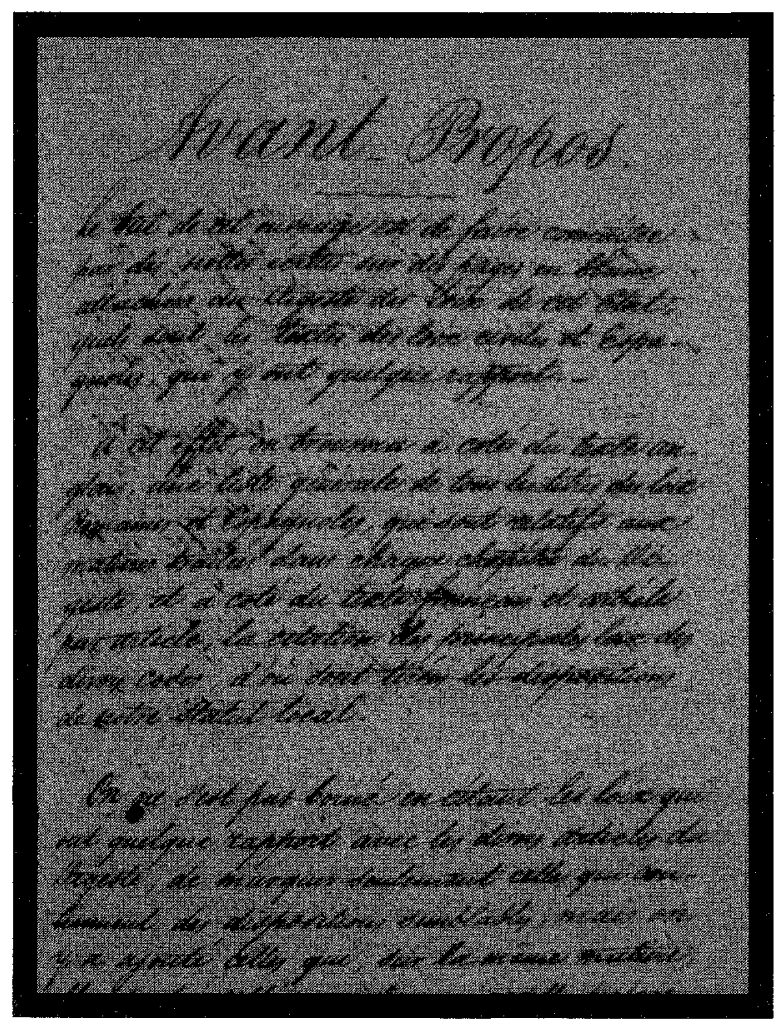

"The purpose of this work is to make known by notes written on the pages in blank attached to the Digest of the Laws of this State, which are the texts of the civil and Spanish laws that have some relation to it."

"To this effect, one will find opposite the English texts, a general list of all the titles of the Roman and Spanish laws, which are related to the matters treated in each chapter of the Digest and opposite the French text and article by article, the citation of the principal laws of the various codes, from which the dispositions of our local statute are drawn." 
Fig. 5.4. Louis Moreau Lislet, A Digest of the Civil Laws Now in Force in the Territory of Orleans (1808); Containing Manuscript References to its Sources and Other Civil Laws on the Same Subjects (the "De La Vergne Volume") (photo. reprint of De La Vergne Volume, Baton Rouge, Louisiana State University 1968) (1808). Photograph by Teresa M. Miguel. This book is held in the Rare Book Room of the Lillian Goldman Law Library, Yale Law School.

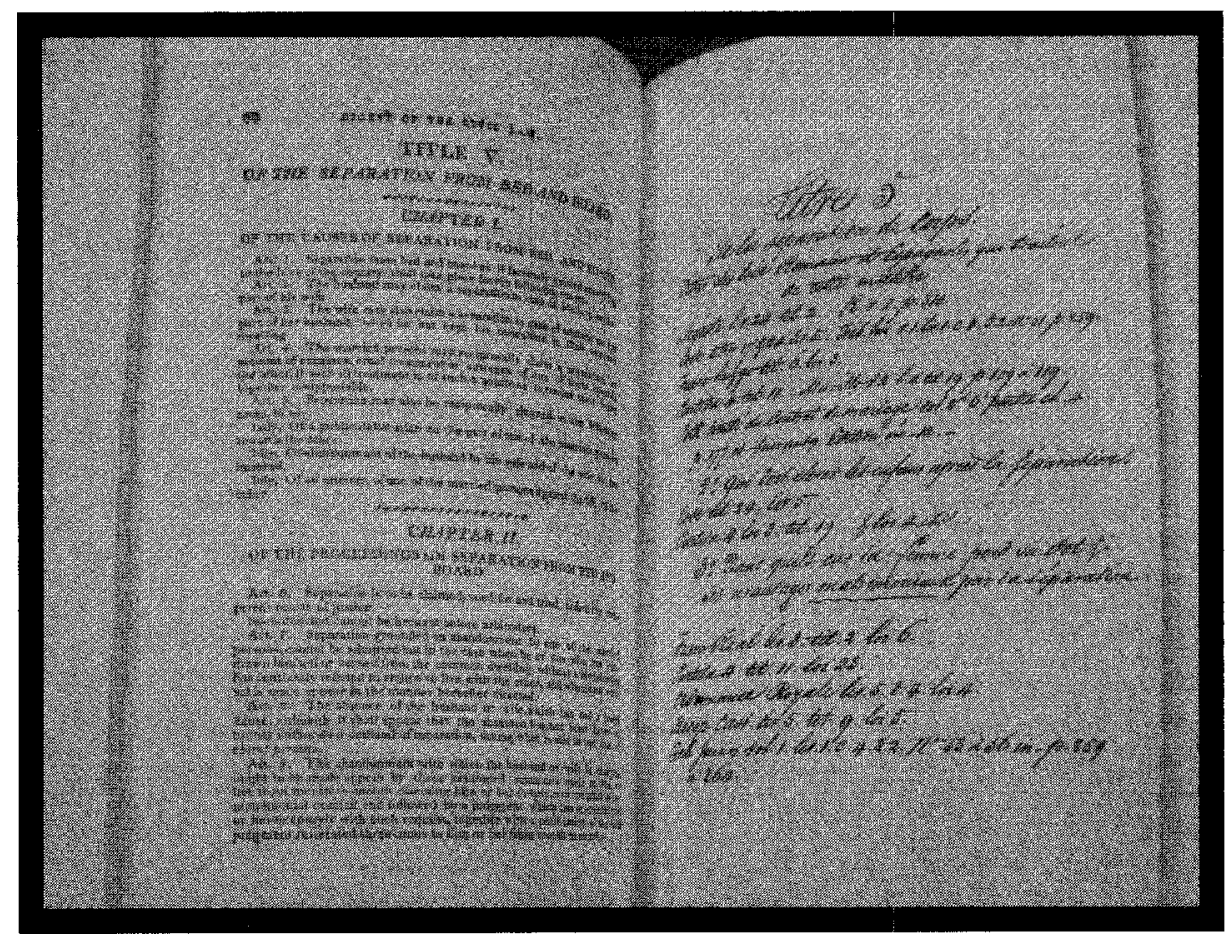


Fig. 6. Moreau Lislet Inventory.

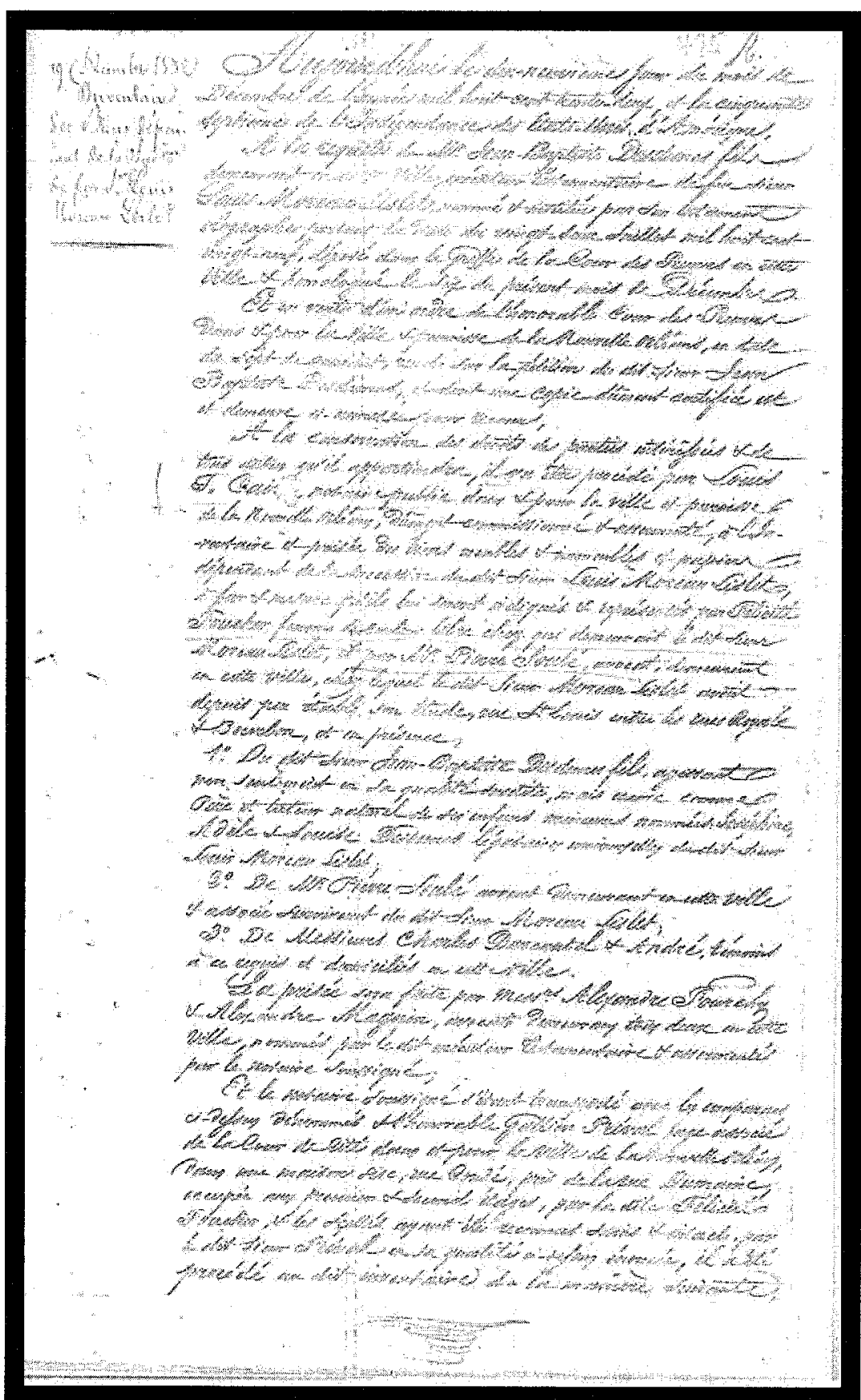


Fig. 7.1. Castile (Kingdom) \& Alfonso X, Las Siete Partidas del Sabio Rey Don Alfonso El Nono: Lyon, M. Bonhomme for A. Gomez and H. Toti 1550 (1254 - 1282). Photograph by Teresa M. Miguel. This book is held in the Rare Book Room of the Lillian Goldman Law Library, Yale Law School.

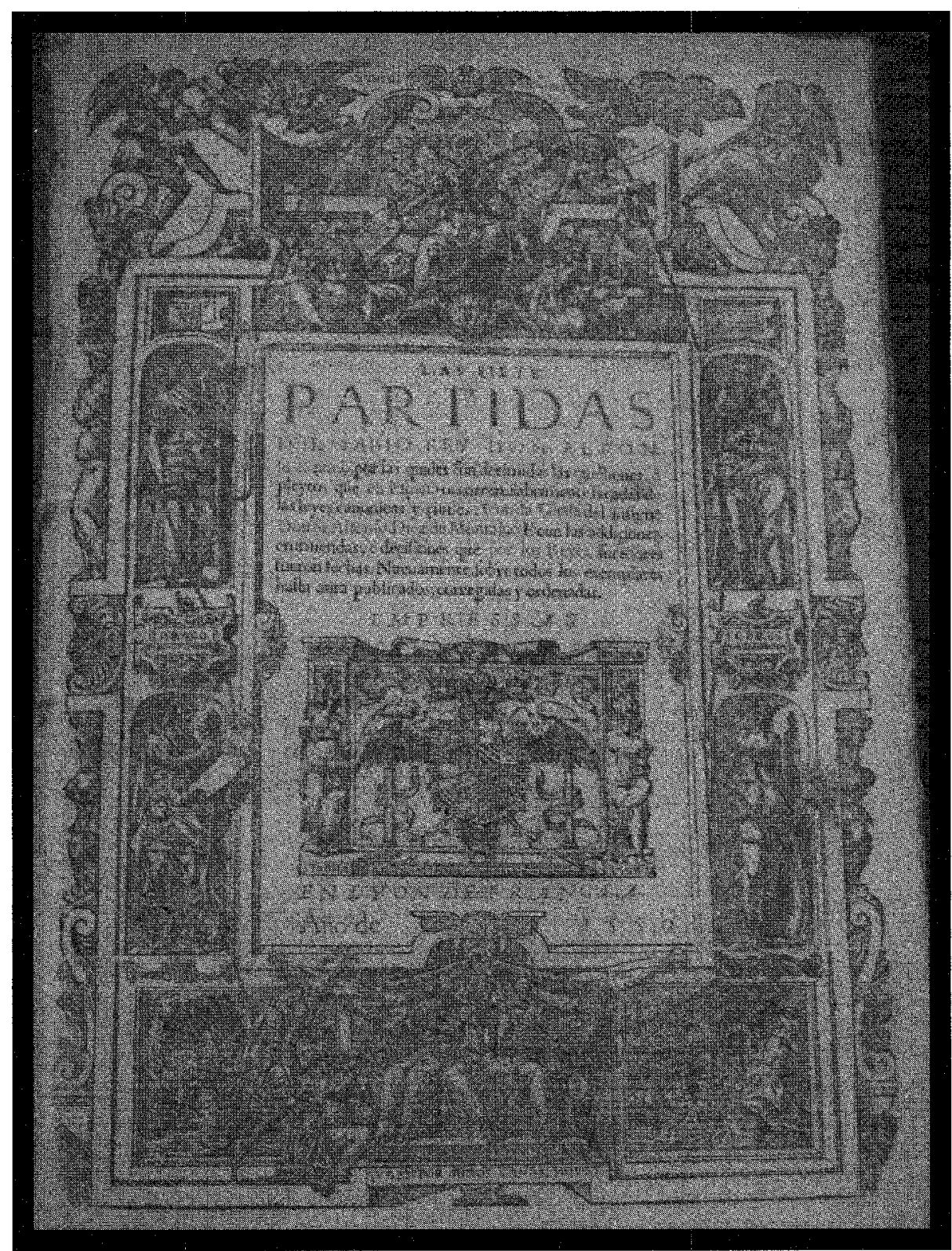


Fig. 7.2. Castile (Kingdom) \& Alfonso X, Las Siete Partidas del Sabio Rey Don Alfonso El Nono. D. Fernandez de Cordoba (1587). Phototograph by Vicenc Feliu. This book is held in the Rare Book Collection of the Paul M. Hebert Law Library, Louisiana State University.

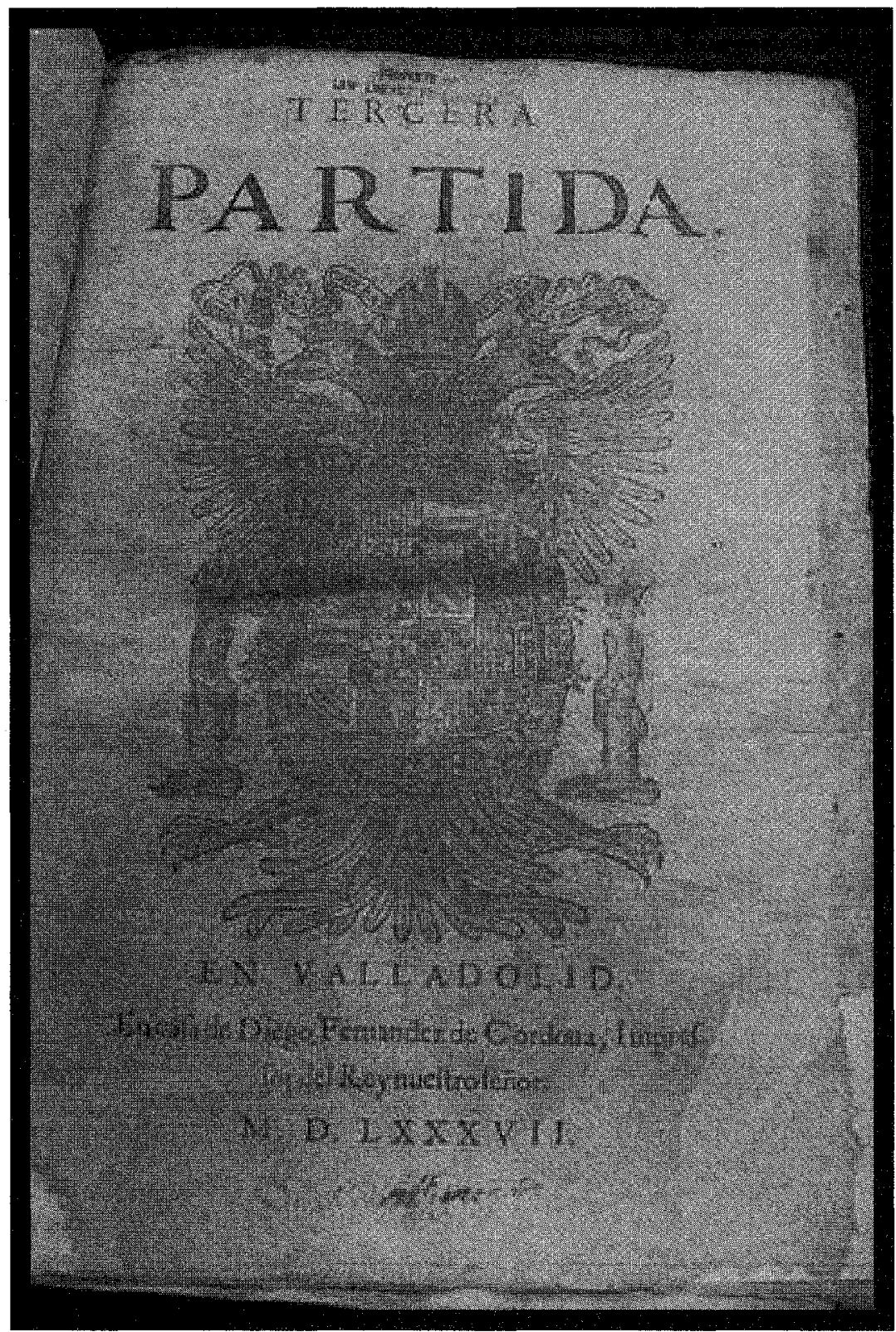


Fig. 8. Castile (Kingdom), Recopilación de Castilla (1775). Phototograph by Vicenc Feliu. This book is held in the Rare Book Collection of the Paul M. Hebert Law Library, Louisiana State University.

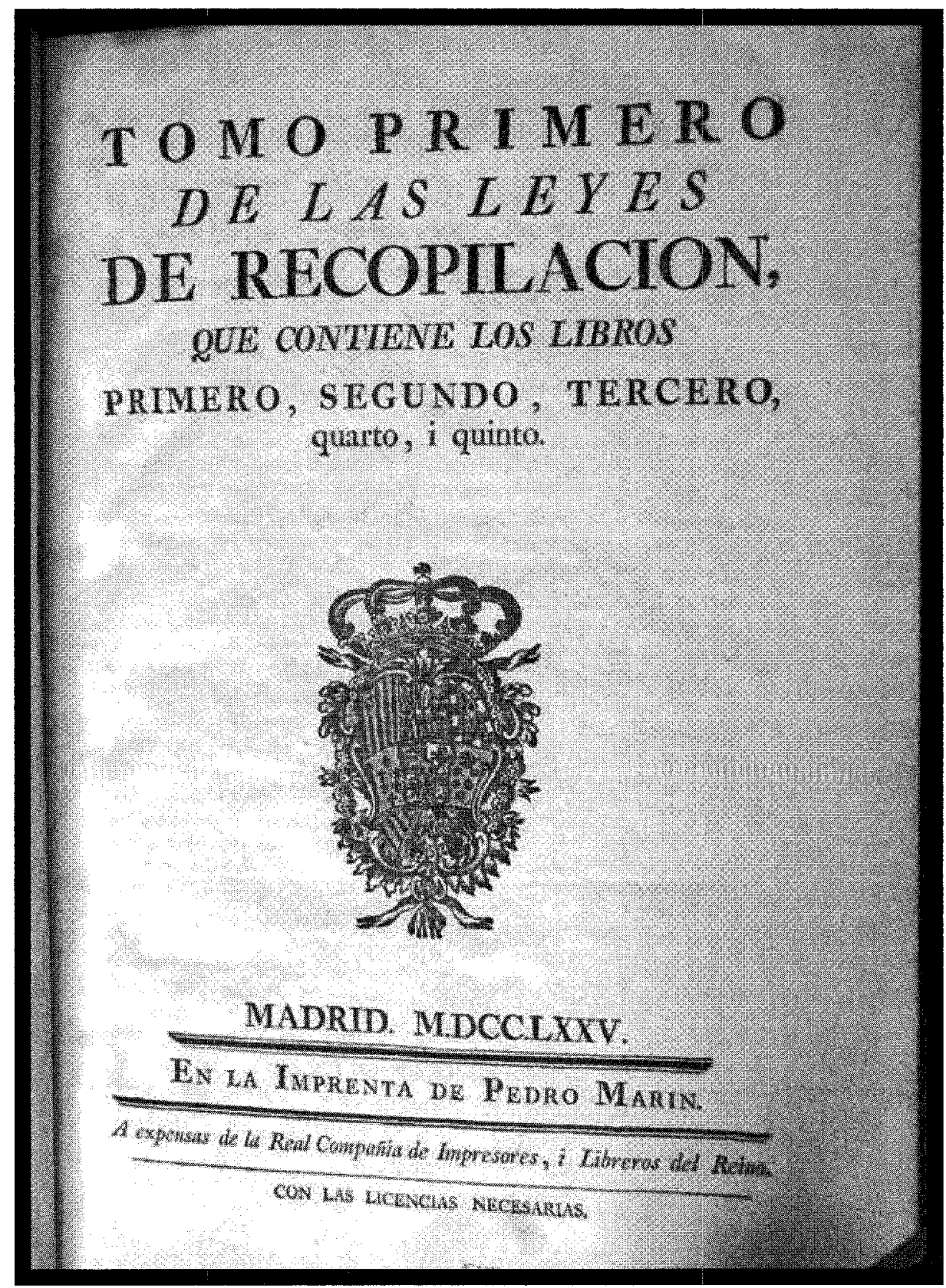


Fig. 9. Castile (Kingdom) \& Diego del Castillo, Las Leyes De Toro Glosadas (Mythymnae Campi, ex typographia Guilielmi de Millis 1553). Photograph by Teresa M. Miguel. This book is held in the Rare Book Room of the Lillian Goldman Law Library, Yale Law School.

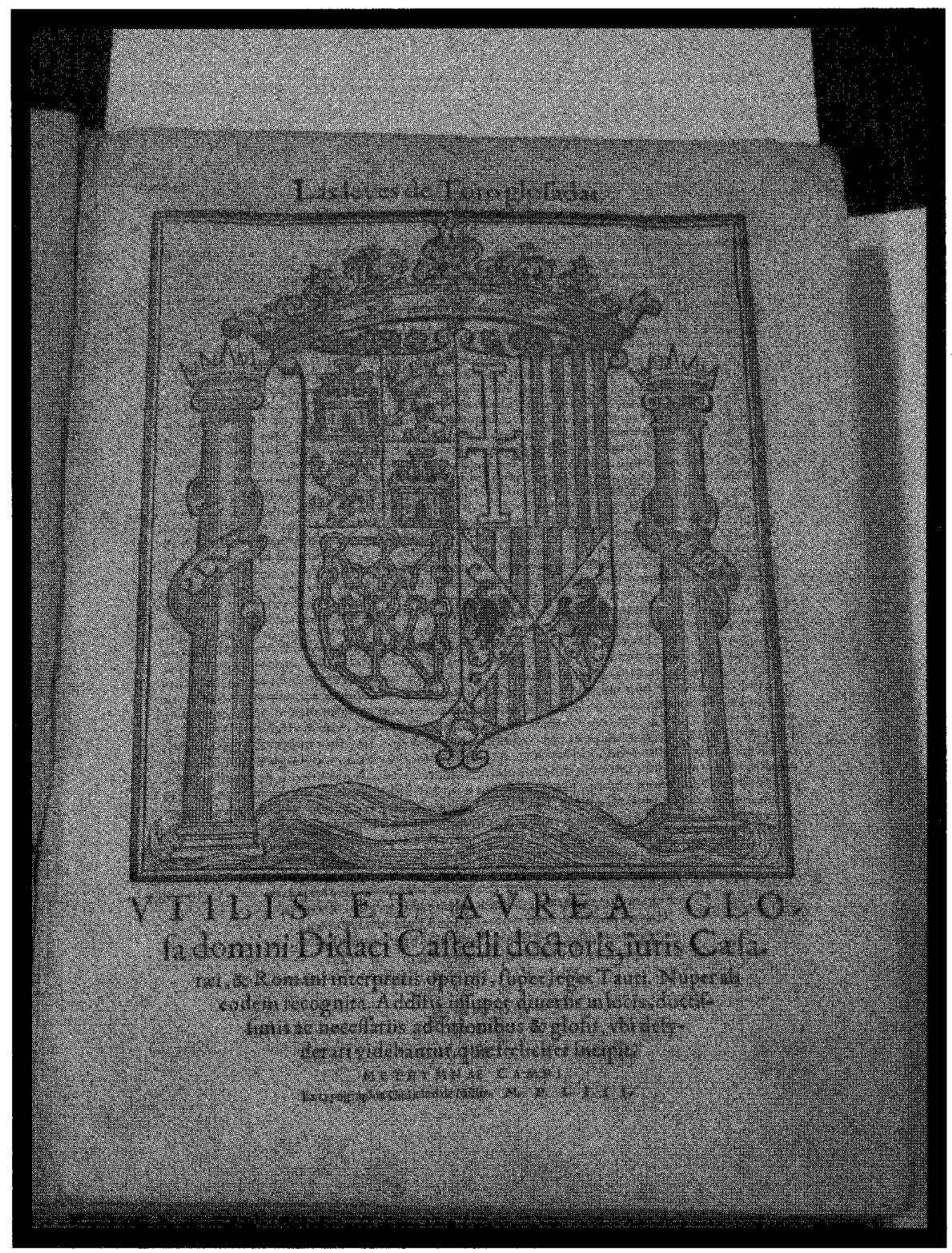


[Vol. 38.3

Fig. 10. Nueva Recopilación(1640). Phototograph by Vicenc Feliu. This book is held in the Rare Book Collection of the Paul M. Hebert Law Library, Louisiana State University.

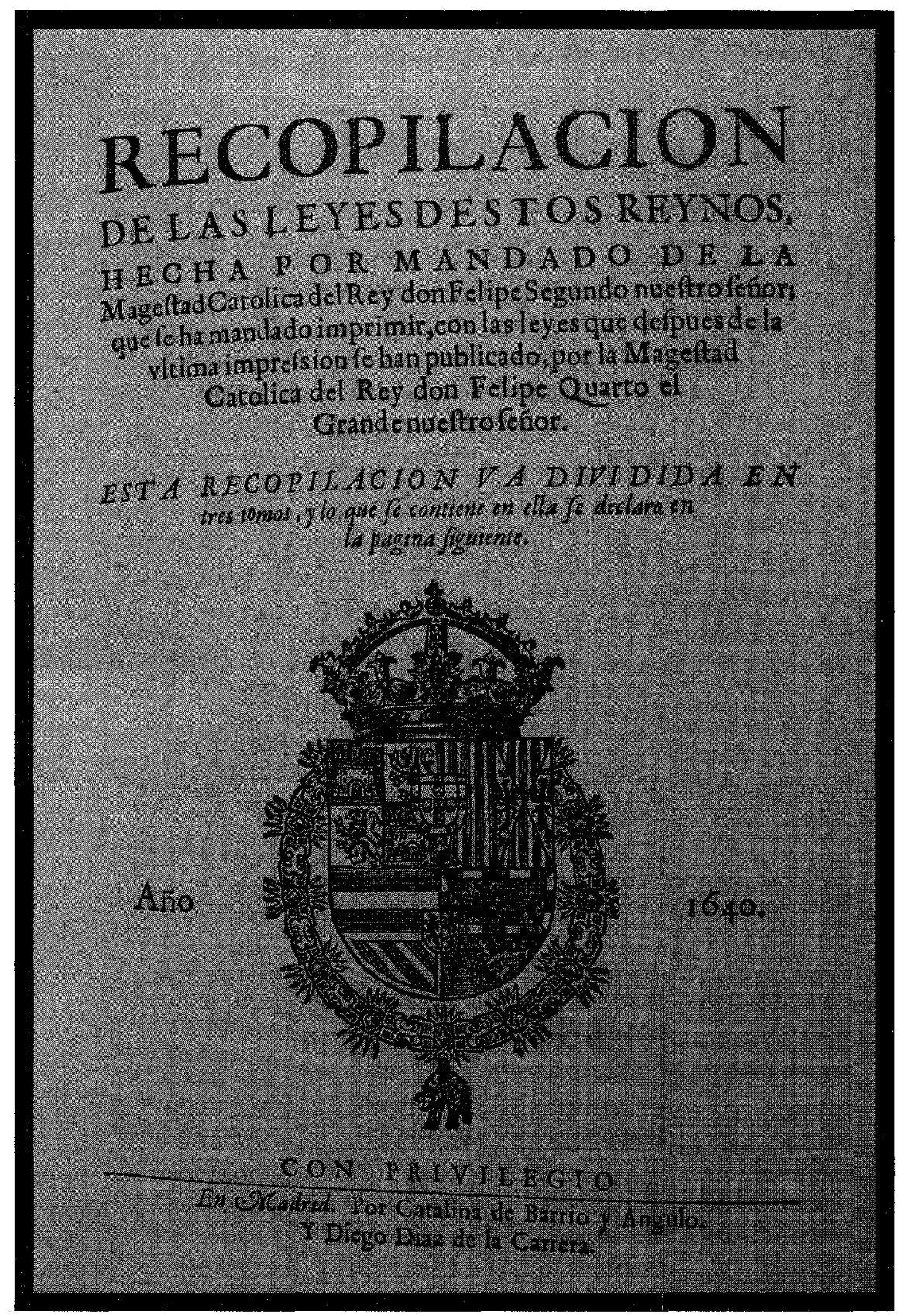


Fig. 11. Spain. Novísima Recopilación de las Leyes de España (Madrid 1805). Phototograph by Vicenc Feliu. This book is held in the Rare Book Collection of the Paul M. Hebert Law Library, Louisiana State University.

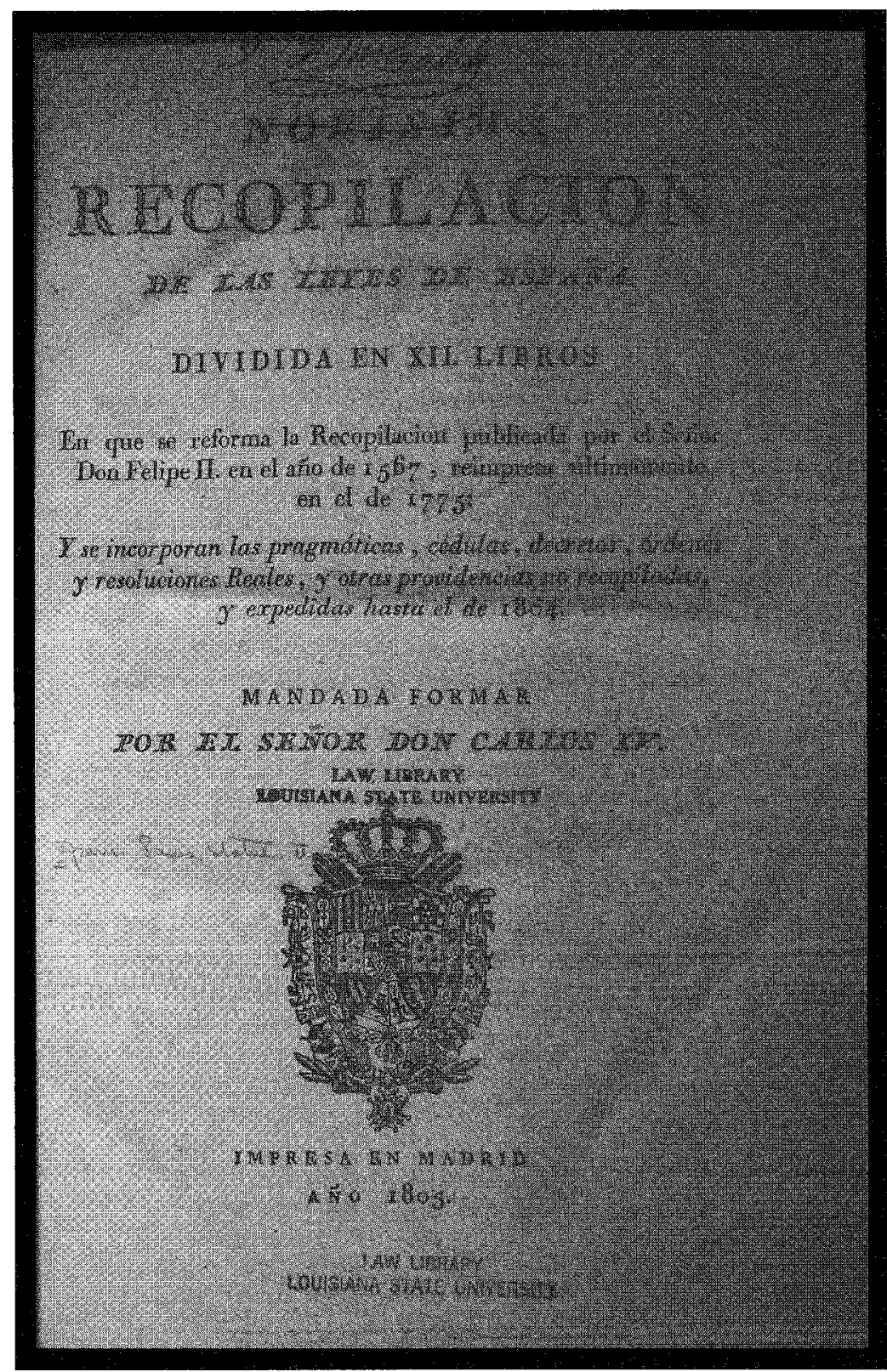


Fig. 12. Spain, Recopilación De Leyes De Los Reynos De Las Indias: Mandadas Imprimir y Publicar Por La Magestad Católica Del Rey Don Carlos II, Nuestro Señor (1756). Phototograph by Vicenc Feliu. This book is held in the Rare Book Collection of the Paul M. Hebert Law Library, Louisiana State University.

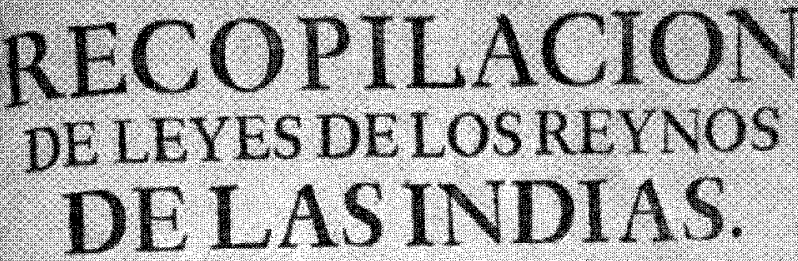

MANDADAS IMPRIMIR , Y PUBLICAR por LA Micest WD CATOH1CA JUL Rer

DON CARLOS II.

\section{NUESTRO SENOR.}

VI DIVIDIDA UN QUATRO TOMOS,

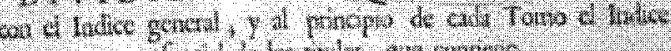

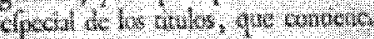

\section{TOMO PRIMERO.}

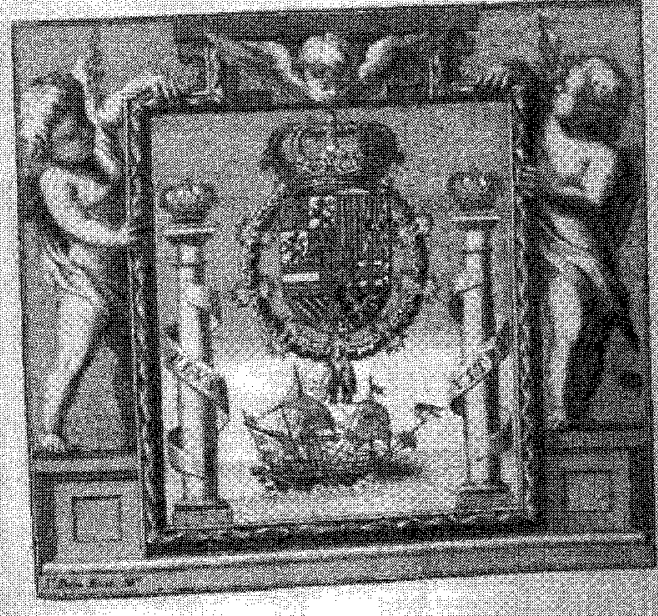

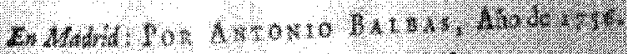

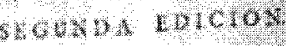


Fig. 13. Aragon (Kingdom), Fueros Reales (1243). Phototograph by Vicenc Feliu. This book is held in the Rare Book Collection of the Paul M. Hebert Law Library, Louisiana State University.

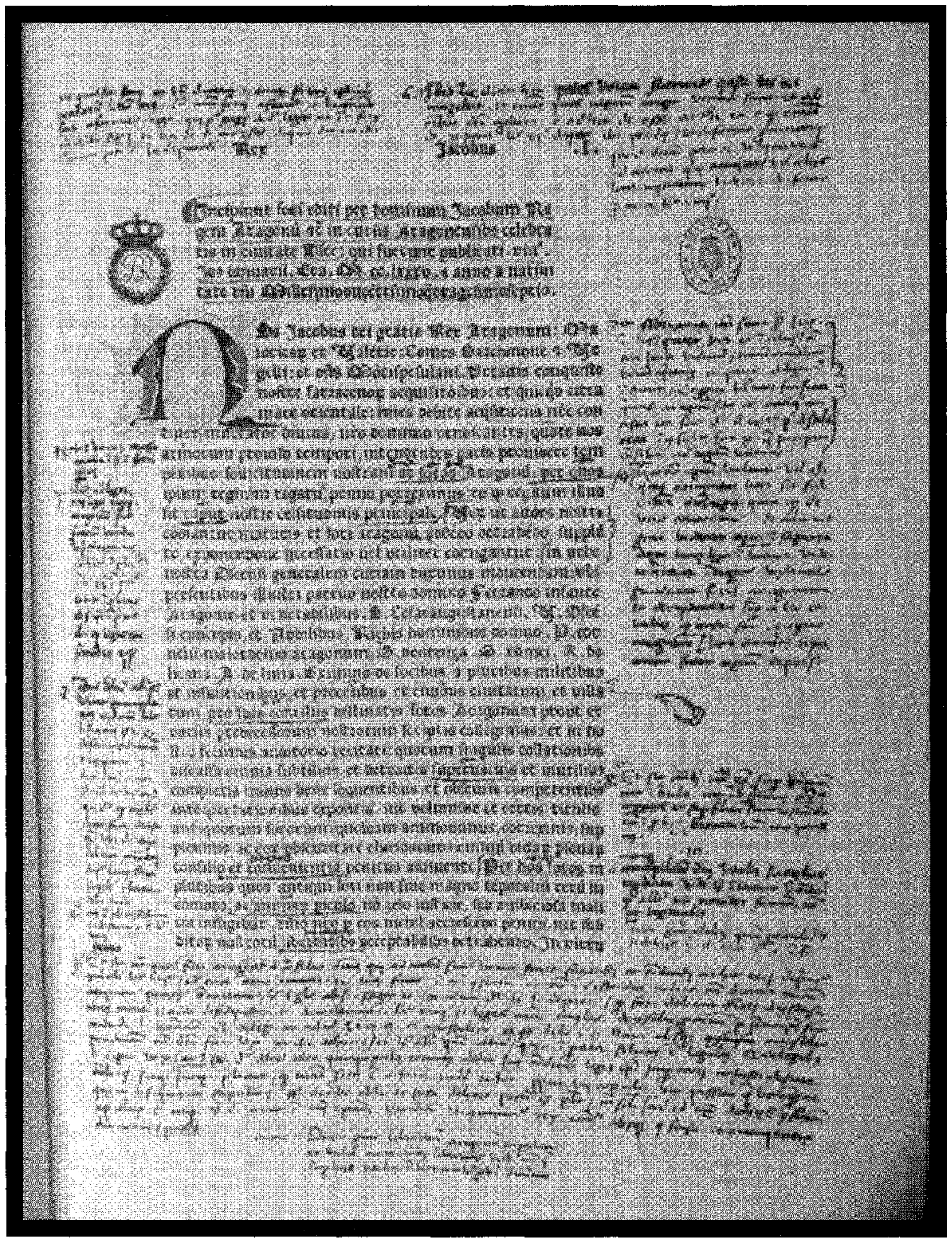


Fig. 14. Juan de Hevia Bolaños, Curia Philipica (1753). Phototograph by Vicenc Feliu. This book is held in the Rare Book Collection of the Paul M. Hebert Law Library, Louisiana State University.

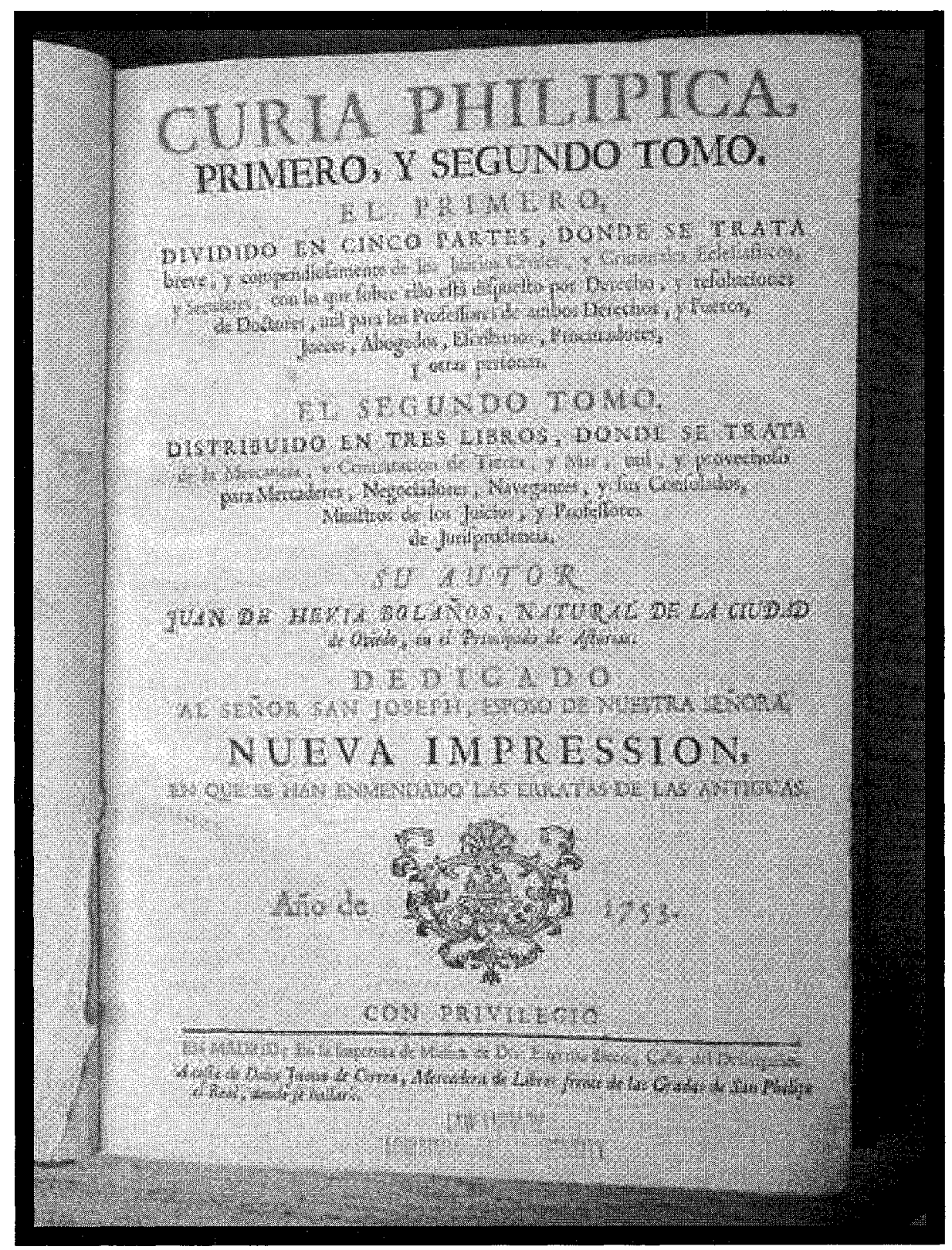


Fig. 15. José Febrero, Febrero Adicionado (1806). Phototograph by Vicenc Feliu. This book is held in the Rare Book Collection of the Paul M. Hebert Law Library, Louisiana State University.

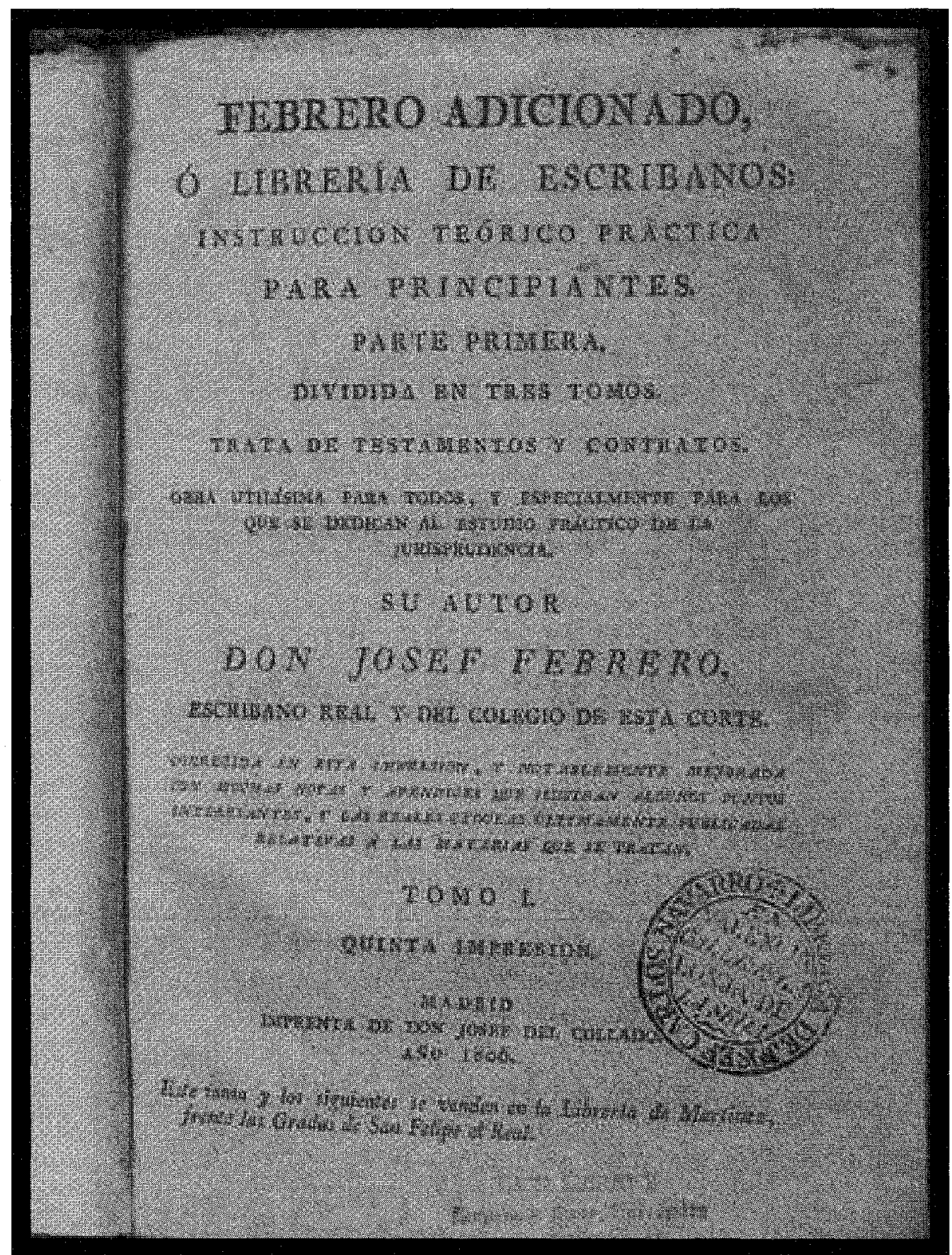


[Vol. 38.3

Fig. 16.1. Louis Moreau Lislet, Henry Carleton \& J. B. Thrasher, The Laws of Las Siete Partidas, which are Still in Force in the State of Louisiana (New Orleans, James M'Karaher 1820). Photograph by Teresa M. Miguel. This book is held in the Rare Book Room of the Lillian Goldman Law Library, Yale Law School.

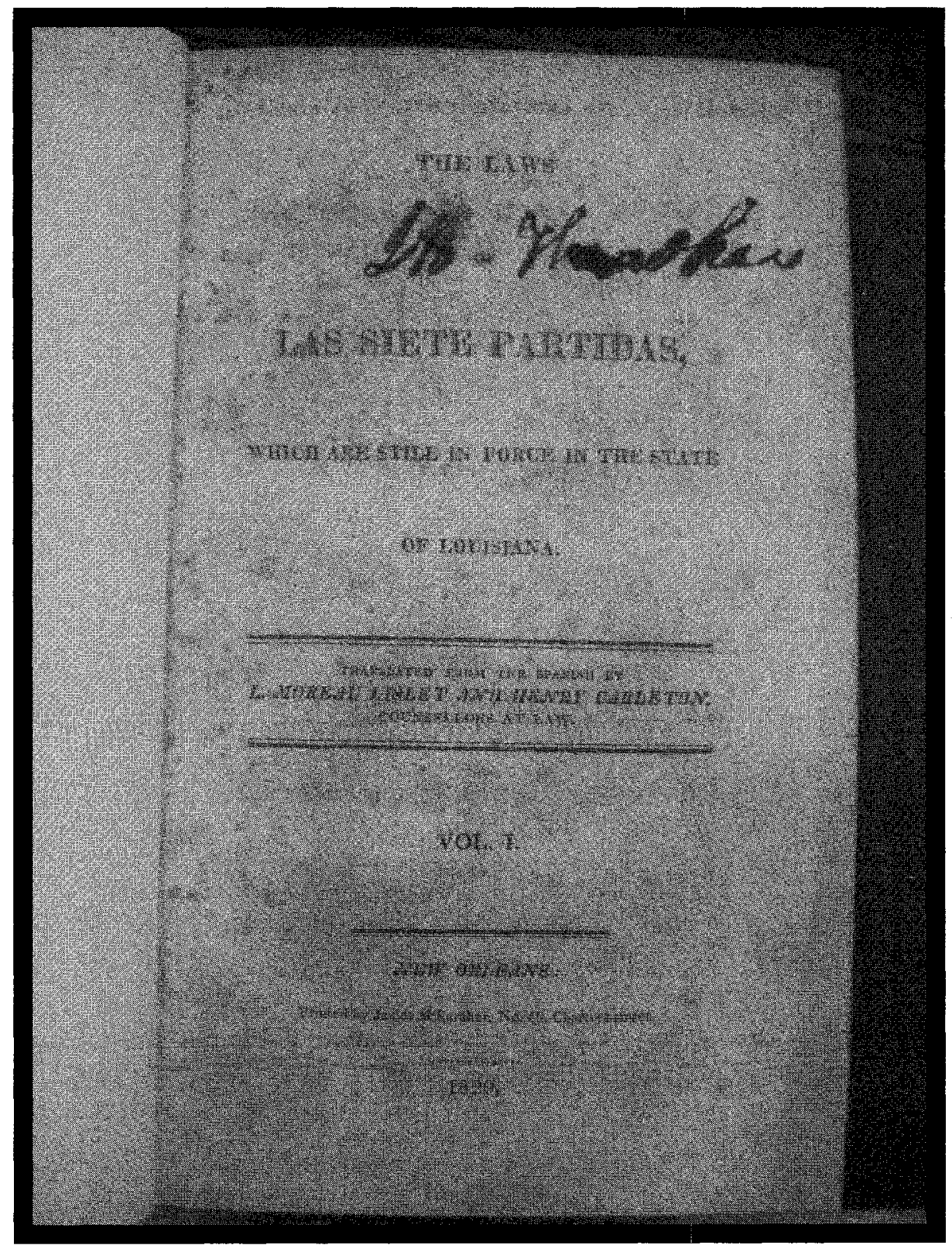


Fig. 16.2 Louis Moreau Lislet, Edward Livingston, \& P. Derbigny, Civil Code of the State of Louisiana (New Orleans, J. C. de St. Romes 1825). Photograph by Teresa M. Miguel. This book is held in the Rare Book Room of the Lillian Goldman Law Library, Yale Law School.

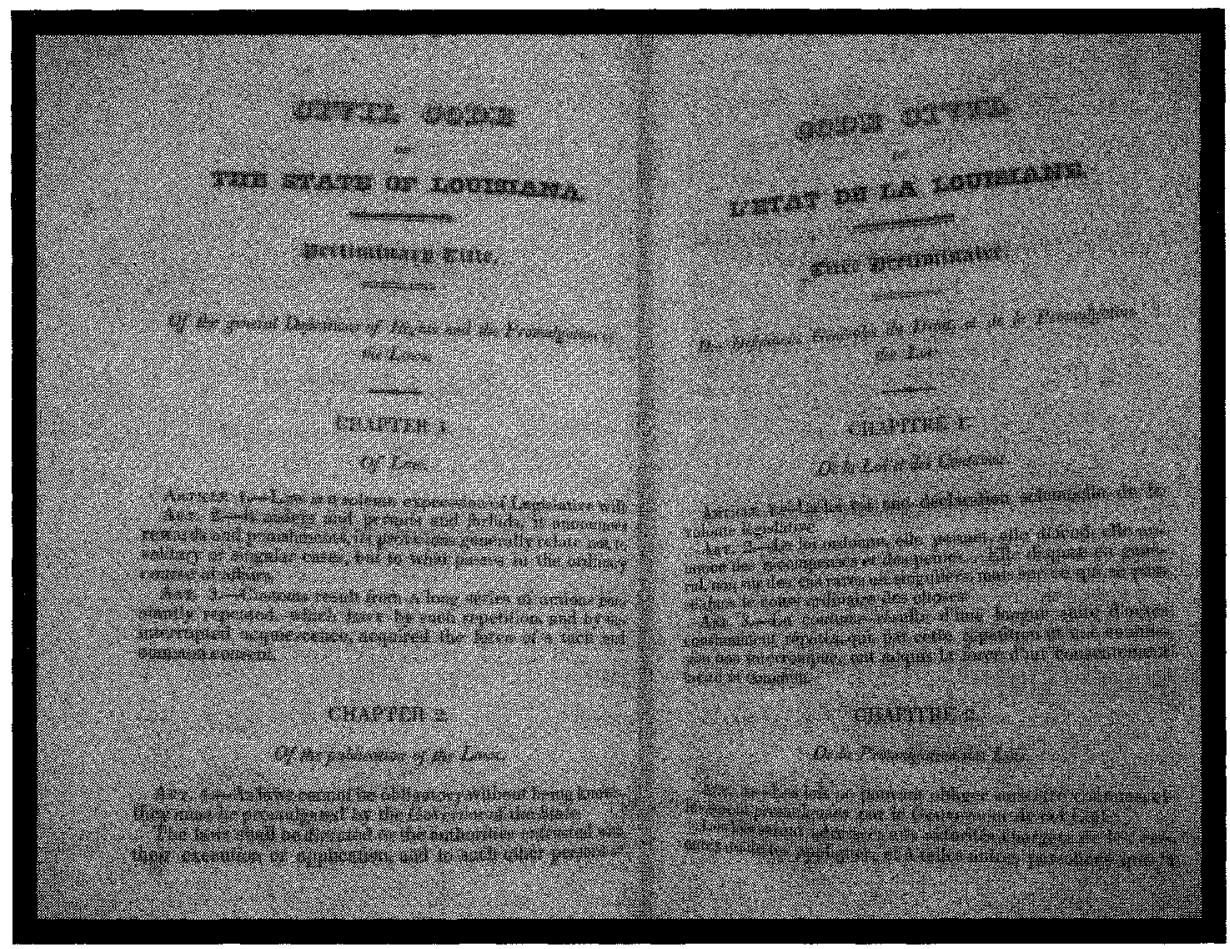


Fig.17. Louisiana Legal Archives: A Republication of the Projet of the Civil Code of Louisiana of 1825 (New Orleans, 1937). Photograph by Teresa M. Miguel. This book is held in the Rare Book Room of the Lillian Goldman Law Library, Yale Law School.

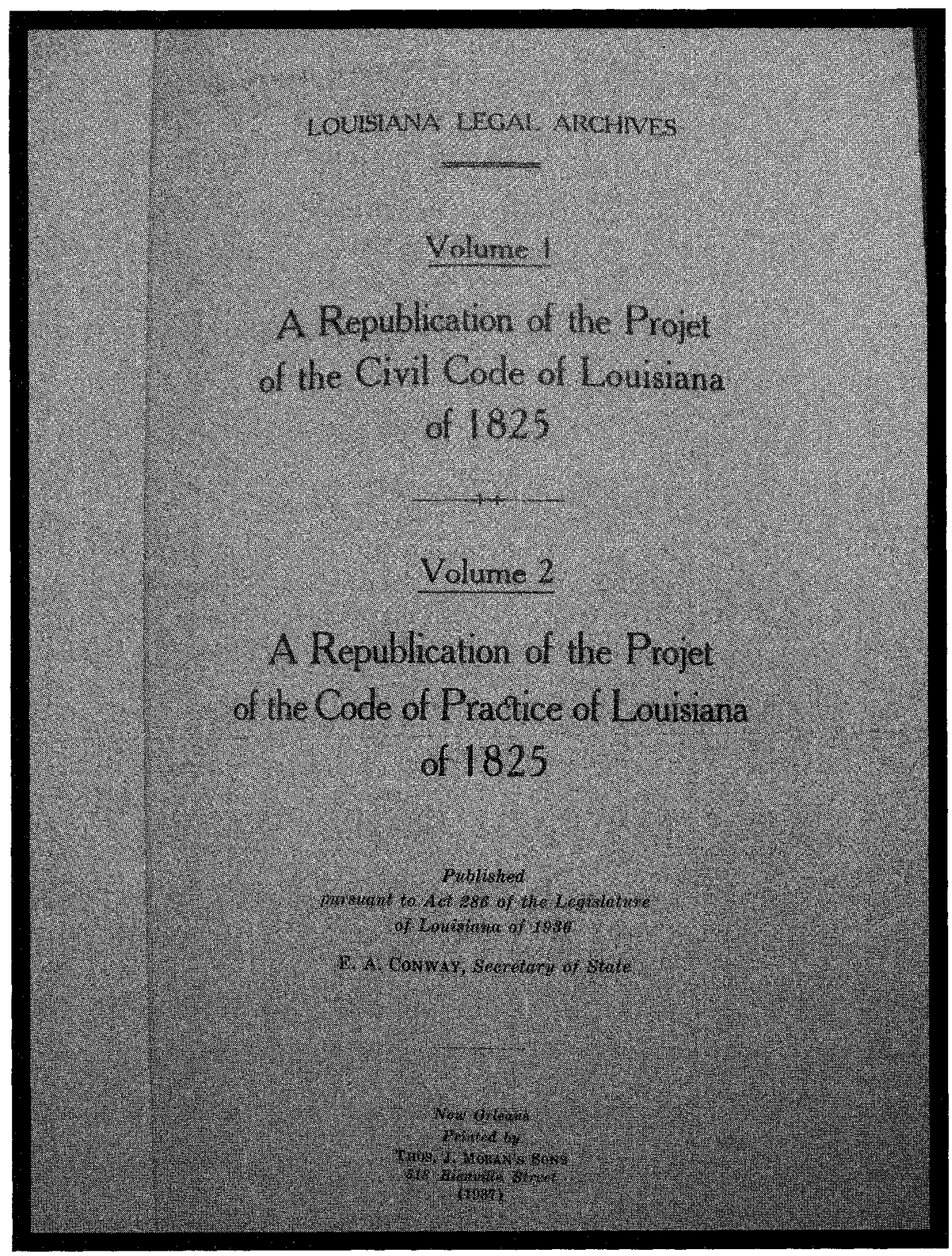

